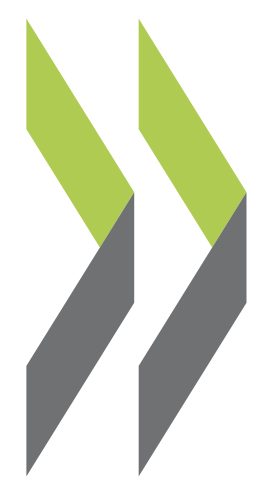

OECD Economics Department Working Papers No. 1685

China's outward direct investment and its impact on the domestic economy

\section{Margit Molnar,}

Ting Yan,

Yusha Li 
ECONOMICS DEPARTMENT

\section{CHINA'S OUTWARD DIRECT INVESTMENT AND ITS IMPACT ON THE DOMESTIC ECONOMY}

\section{ECONOMICS DEPARTMENT WORKING PAPERS No. 1685}

By Margit Molnar, Ting Yan and Yusha Li

OECD Working Papers should not be reported as representing the official views of the OECD or of its member countries. The opinions expressed and arguments employed are those of the author(s).

Authorised for publication by Isabell Koske, Deputy Director, Country Studies Branch, Economics Department.

All Economics Department Working Papers are available at www.oecd.org/eco/workingpapers. 
OECD Working Papers should not be reported as representing the official views of the OECD or of its member countries. The opinions expressed and arguments employed are those of the author(s).

Working Papers describe preliminary results or research in progress by the author(s) and are published to stimulate discussion on a broad range of issues on which the OECD works.

Comments on Working Papers are welcomed, and may be sent to OECD Economics Department, 2 rue André Pascal, 75775 Paris Cedex 16, France, or by e-mail to eco.contact@oecd.org.

All Economics Department Working Papers are available at www.oecd.org/eco/workingpapers.

This document and any map included herein are without prejudice to the status of or sovereignty over any territory, to the delimitation of international frontiers and boundaries and to the name of any territory, city or area.

The statistical data for Israel are supplied by and under the responsibility of the relevant Israeli authorities. The use of such data by the OECD is without prejudice to the status of the Golan Heights, East Jerusalem and Israeli settlements in the West Bank under the terms of international law.

On 3 May 2018, the OECD Council invited Lithuania to become a Member. At the time of preparation the deposit of Lithuania's instrument of accession to the OECD Convention was pending and therefore Lithuania does not appear in the list of OECD Members and is not included in the OECD zone aggregates.

On 25 May 2018, the OECD Council invited Colombia to become a Member. At the time of preparation the deposit of Colombia's instrument of accession to the OECD Convention was pending and therefore Colombia does not appear in the list of OECD Members and is not included in the OECD zone aggregates.

\section{(C) OECD (2021)}

You can copy, download or print OECD content for your own use, and you can include excerpts from OECD publications, databases and multimedia products in your own documents, presentations, blogs, websites and teaching materials, provided that suitable acknowledgment of OECD as source and copyright owner is given. All requests for commercial use and translation rights should be submitted to PubRights@oecd.org. 


\section{ABSTRACT/RESUMÉ}

\section{China's outward direct investment and its impact on the domestic economy}

Overseas direct investment by Chinese firms increased eight fold over the past decade, making the country as an important investor in stock terms as Japan. Investing in leasing and business services appears to make up nearly half of China's ODI stock according to official sources, though it is over-estimated owing to the fact that all investment through third parties and vehicles appears under this sector, not under the one where the investment is actually made. Correcting for this caveat by using firm-level M\&A and greenfield investment data indicates that in fact China's ODI mostly goes to resource-based manufacturing. Also, China is just as an important manufacturing investor as is Japan. Estimation results show that overseas direct investment affects domestic employment negatively in the majority of sectors, indicating substitution instead of a complementary relationship. Furthermore, ODI reduces the speed of labour market adjustment to its long-run equilibrium and increases the domestic price elasticity of demand for labour. There is considerable heterogeneity across sectors, but the impact of ODI on domestic fixed asset investment tends to be negative in most sectors.

This Working Paper relates to the 2019 Economic Survey of China (http://www.oecd.org/economy/chinaeconomic-snapshot/).

JEL classification: F21, F23, F62, F63, F66

Keywords: overseas direct investment, ODI, M\&A, greenfield investment, labour market adjustment, fixed asset investment

\section{L'investissement direct étranger sortant chinois et son effet sur l'économie intérieure}

L'investissement direct à l'étranger (IDE) des entreprises chinoises a été multiplié par 8 au cours des dix dernières années, faisant de la Chine un investisseur aussi important que le Japon en termes de stocks. Les investissements dans le secteur du crédit-bail et des services aux entreprises représentent près de la moitié du stock d'IDE d'après les sources officielles. Cette proportion est cependant surestimée, car tous les investissements réalisés par des parties tierces ou des structures d'investissement sont comptabilisés dans ce secteur et non dans leur secteur de destination. Après correction à l'aide des données par entreprise sur les investissements liés aux fusions-acquisitions et les investissements de création, il apparaît que l'essentiel de l'IDE chinois est destiné aux industries manufacturières reposant sur des ressources naturelles. Par ailleurs, la Chine est un aussi grand investisseur dans le secteur manufacturier que le Japon. Des estimations montrent que l'investissement direct à l'étranger a un effet négatif sur l'économie nationale, signe qu'ils sont substituables et non complémentaires. En outre, l'IDE réduit la vitesse d'ajustement du marché du travail à son équilibre de long terme et fait augmenter l'élasticité prix de la demande de travail dans l'économie nationale. L'effet de l'IDE sur l'investissement en actifs fixes varie selon les secteurs, du fait de leur forte hétérogénéité, mais il est négatif dans la plupart des cas.

Ce Document de travail se rapporte à l'Étude économique de la Chine 2019 (http://www.oecd.org/fr/economie/chine-en-un-coup-d-oeil/).

Classification JEL: F21, F23, F62, F63, F66

Mots-clés: investissement direct à l'étranger, IDE, fusions-acquisitions, investissement de création, ajustement du marché du travail, investissement en actifs fixes 


\section{Table of contents}

China's outward direct investment and its impact on the domestic economy

Introduction - Current policy framework and the "Going out strategy" 6

A snapshot of China's overseas direct investment 8

Overall trends

The geographical dimension 13

The sectoral dimension 16

The sectoral dimension in major destinations 22

The impact of China's overseas direct investment on its domestic employment 23

Gauging the impact of ODI on domestic employment and description of data 23

The impact of ODI on domestic investment 28

$\begin{array}{ll}\text { Wrapping up } & 30\end{array}$

References $\quad 31$

Annex A. Chinese ODI by the official data 32

Annex B. Industry concordance for the M\&A and greenfield databases 37

Annex C. Definition and source of variables $\quad 49$

Employment $\quad 49$

Value added $\quad 49$

Output $\quad 50$

Fixed asset investment $\quad 50$

Wage $\quad 50$

Deflators $\quad 50$

\section{Tables}

Table 1. Many economies relay heavily on China for foreign investment

Table 2. ODI reduces domestic employment and the price elasticity of labour demand and increases the speed of adjustment

Table 3. ODI reduces labour demand in some labour-intensive manufacturing industries 26

Table 4. The overall impact of ODI on fixed asset investment is not statistically significant 28

Table 5. Outward direct investment tends to have a negative impact on fixed asset investment 29

Table A B.1. Concordance of Chinese sector classification and SIC 37

Table A B.2. Concordance of Chinese national classification and the FDI Markets database's sector classification 


\section{Figures}

Figure 1. Outward direct investment soared and forex reserves shrank in 2015-17

Figure 2. Chinese overseas investment surged but remains a small share of the world's total 9

Figure 3. China's relative importance as an investor increased sharply over the past decade 9

Figure 4. Mergers and acquisitions have been a more important way of outward direct investment than greenfield

Figure 5. M\&A deals have increased while greenfield projects decreased in size in 2017

Figure 6. Most Chinese ODI comes from coastal provinces and municipalities

Figure 7. Listed firms have been the major acquirers 13

Figure 8. The United States is the major destination for China's ODI, followed by Hong Kong, China in $2017 \quad 14$

Figure 9. The United States tops Chinese greenfield investment and M\&A destinations - based on greenfield project and M\&A deal data

Figure 10. Top 20 cities receiving Chinese greenfield investment

Figure 11. China's manufacturing ODI grew three-fold over the past five years and is concentrated in resource-based industries

Figure 12. Most ODI goes to manufacturing and finance

Figure 13. Overseas job creation by Chinese affiliates, $2017 \quad 19$

Figure 14. China's manufacturing ODI stock has exceeded Japan's 20

Figure 15. China is the leading investor in construction services and utilities, but not in services, in general 21

Figure 16. China is world leader in ODI stock in transportation and related services, but invests little in commerce and finance

Figure 17. Chinese ODI in advanced economies goes mainly to manufacturing and finance 23

Figure A.1. The United States is the major destination of Chinese ODI

Figure A.2. In recent years, Chinese ODI to the United States by the official data are higher than US official data suggest

Figure A.3. In finance, IT and wholesale and retail trade there are large discrepancies in China's ODI to the United States and US FDI from China

Figure A.4. Most Chinese ODI goes to services, in particular leasing and business services

Figure A.5. China's manufacturing ODI stock grew rapidly

Figure A.6. The manufacturing ODI stock is of similar size of Korea's by MOFCOM data and of Japan's from greenfield projects and M\&A deals data

Figure A.7. Official data indicate that most ODI in finance, transport and real estate goes to Hong Kong, China 35 


\title{
China's outward direct investment and its impact on the domestic economy
}

\author{
By Margit Molnar, Ting Yan and Yusha $\mathrm{Li}^{1}$
}

\section{Introduction - Current policy framework and the "Going out strategy"}

1. In the past few years, China's outward foreign direct investment (ODI) picked up sharply and raised concerns as it coincided with the fall in foreign exchange reserves. A noteworthy change in the pattern of outward investment is the increasing number of private companies venturing overseas. According to official speeches, as of 2017 , roughly $70 \%$ of new Chinese ODI was made by private firms. Official ODI stock data indicate that indeed in 2017, for the first time, non-state owned enterprise investment (including individual private investors) overtook ODI by state-owned enterprises with a $50.9 \%$ share almost tripling over the past decade. Easing liquidity conditions for private firms as well as technology seeking and extending marketing channels overseas were major conditions behind the surge of private ODI. De Beule et al. (2018) showed that Chinese firms tend to follow other Chinese investors not only in the same sector but also in other sectors in European Union countries. This observation is stronger in the case of private firms than state-owned enterprises. Another emerging pattern in the last few years is mergers and acquisitions increasingly targeting real estate, hotels, entertainment firms and sports clubs. Seeking higher return on capital was the major motive behind such shifting from upstream to downstream investment (HSBC, 2016). This development has caught the attention of the Chinese leadership and has been pointed out on a number of occasions as the dark side of soaring overseas direct investment activities.

2. The "going out" strategy was first discussed at the People's Congress meeting in March 2000 and then became one of the four new strategies of the 10th Five Year Plan (along with the Western development, the urbanisation and the skills strategies) and five years later, "going out" of private firms was specifically encouraged in official documents. In about a decade from then, several private firms have come under spotlight as they have been expanding too rapidly overseas and their expansion has been financed by ever-increasing debt. While capital outflows have been crucial in acquiring foreign technology and upgrading industries and under the aegis of "going out" also to boost profits, very often they involved profit hiding or money laundering. To rein in such activities, the authorities adopted various forms of capital control measures with varying degrees of success. Implicit window guidance was introduced in early 2016. In 2017, the National Development and Reform Commission, the Ministry of Commerce, the People's Bank

\footnotetext{
${ }^{1}$ Margit Molnar is Head of the China Desk at the OECD Economics Department and Ting Yan and Yusha Li were Research Assistants there when writing the paper. The authors would like to thank Alvaro Pereira, Isabell Koske, Patrick Lenain and Nigel Pain from the Economics Department and Stephen Thomsen from the Directorate for Financial and Enterprise Affairs for their useful comments and Karimatou Diallo and Stephanie Henry for editorial assistance.
} 
of China, the Ministry of Foreign Affairs and the All China Business Federation jointly issued standards for investment and operation of private firms overseas. Furthermore, more stringent monitoring of capital outflows was introduced and authorities blocked transfers from multiple domestic accounts to a single overseas account as a way of tackling the problem of illicit capital outflows. In the end, curbing capital outflows helped halt the decline in reserves seen between 2015 and 2017 (Figure 1). In more recent years, ODI has been more stable and the fluctuations in foreign exchange reserves less volatile.

\section{Figure 1. Outward direct investment soared and forex reserves shrank in 2015-17}

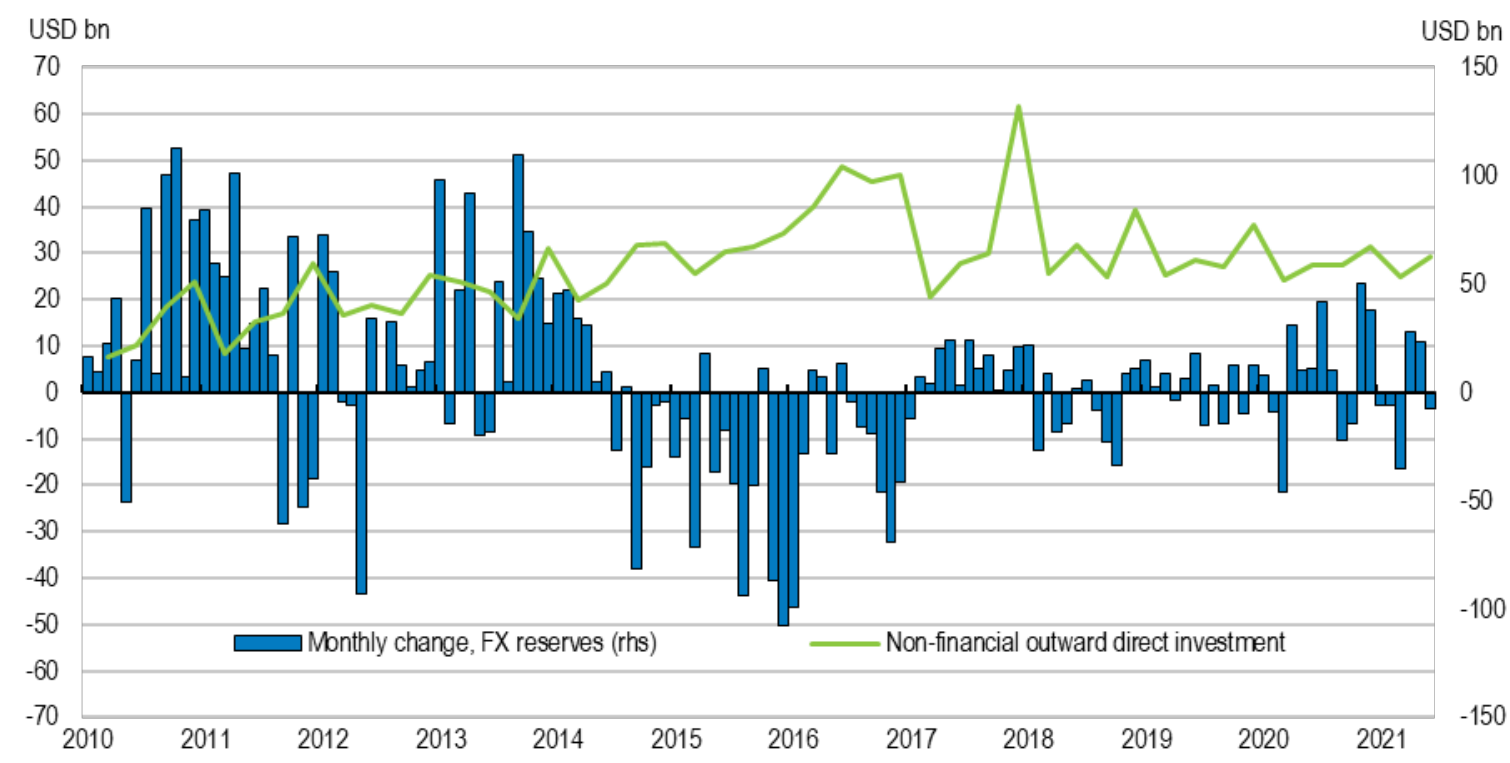

Source: CEIC database.

3. As a more permanent measure to address the issue, the National Development and Reform Commission issued Order No. 11 related to the promulgation of Administrative Measures for Overseas Investment by Enterprises and the Catalogue of Sensitive Industries for Overseas Investment, effective from March 2018. Indeed, since the Measures and the Catalogue, capital appears to have harder time to flee the country. The new measures replaced the 2014 approval system with a notification regime below investment of USD 300 million in non-sensitive industries or regions. Sensitive industries listed in the Catalogue including research, production or maintenance of weaponry, development and utilisation of cross-border water resources and press and media require approval by NDRC. Approval or rejection is based on the project's authenticity and whether it conforms to relevant regulations.

4. As the 2019 OECD Economic Survey of China advocates, to halt money-laundering practices under the disguise of foreign direct investment, all investment, including by overseas affiliates should be reported. Furthermore, as in major investor countries, such as the United States, Japan or Germany, collecting basic data related to affiliates (i.e. FATS or foreign affiliate trade statistics data) such as their sales (by destination), input sourcing (by source country) employment, investment etc. would help monitoring and evaluating overseas investment. Accounts of foreign affiliates of state-owned enterprises (SOEs) should be regularly audited to avoid loss of state assets. SOEs have an increasing share of their assets overseas, rising from $3.8 \%$ in 2005 to over $9 \%$ in 2017 for non-financial SOEs. Li et al. (2018) showed that overseas deal completion rate by SOEs was $14 \%$ lower than that of other firms and that the lower probability is related to SOEs' opaqueness. With protectionism gaining ground worldwide, Chinese acquirers have been facing greater scrutiny, particularly in sensitive sectors with national security ramifications. This, coupled with more stringent domestic stance on capital outflows, curbed outward M\&A 


\section{8 | ECO/WKP(2021)36}

deals in 2017. The prospects for ODI are shadowed also by trade disputes, which may even reorient value chains. Firms previously investing in mines overseas to import minerals and process them domestically now may need to re-think their business model if tariffs hurt on either or both ways. Higher commodity and raw material prices may encourage more expensive extraction and investment in technologies that used to be too expensive.

5. In light of the recent controversies surrounding overseas direct investment, this paper takes stock of Chinese overseas direct investment from a global point of view, looking at its share in aggregate direct investment, its distribution across destinations and sectors, its sources and its importance for some of the destinations. Official ODI statistics suffer from the caveat of classifying all investment through third party vehicles as investment in leasing and business, irrespective of which sector the investment is actually made. A novelty of this paper is that it corrects for this caveat by using firm-level micro-data of actual investment, including both greenfield and M\&As. Another caveat of official data is that it does not take into account ODI to the extent it is financed by overseas borrowing. This paper also corrects for that by looking at the actual size of firm-level ODI, irrespective of the source of funding. After taking stock of the trends based on the newly constructed dataset, which is more comparable to international statistics, the paper investigates the impacts of ODI on the domestic economy. There have been some concerns in recent years in some locations in Eastern China that there is an exodus of labour-intensive industries to countries with lower wages and that the hollowing out of the economy, experienced by Japan decades ago, may also be an issue in China. To address these concerns, empirical analysis of the impact of ODI on domestic employment and investment are conducted.

\section{A snapshot of China's overseas direct investment}

\section{Overall trends}

6. The stock of overseas Chinese direct investment increased 8 folds in the past decade or so (and 60 folds by 2018 relative to 2003) - (Figure A.2). In 2015, in terms of flows, China overtook Japan, becoming the second largest investor in the world. However, in terms of ODI stock, China commanded USD 2.4 trillion, a tiny $6.4 \%$ of the world total in 2020 (Figure 2 Panel B). Nevertheless, China's share of global direct investment has more than doubled over the past five years and increased over five folds over the past decade (Figure 3). At the same time, other major investors' share remained stable or even shrank with the exception of that of Japan. 
Figure 2. Chinese overseas investment surged but remains a small share of the world's total

\section{A. ODI by Chinese firms increased 8 fold in the past} ten years USD bn

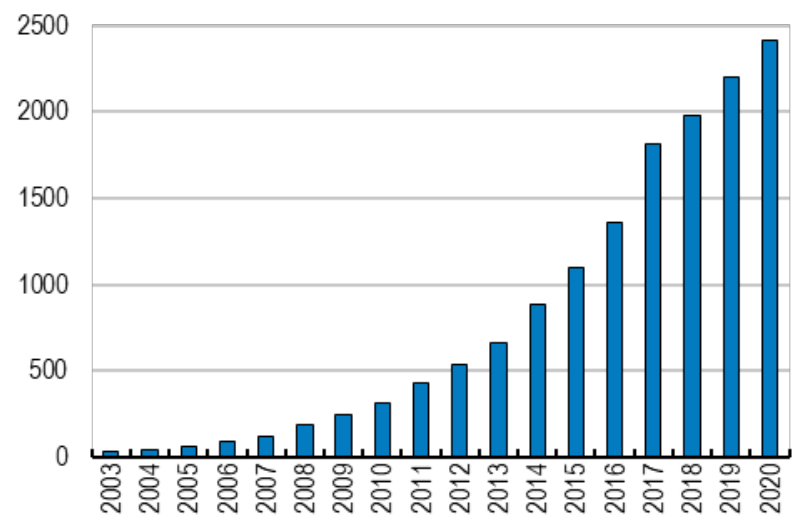

\section{B. ...but it is still a tiny share of the world total,} 2020

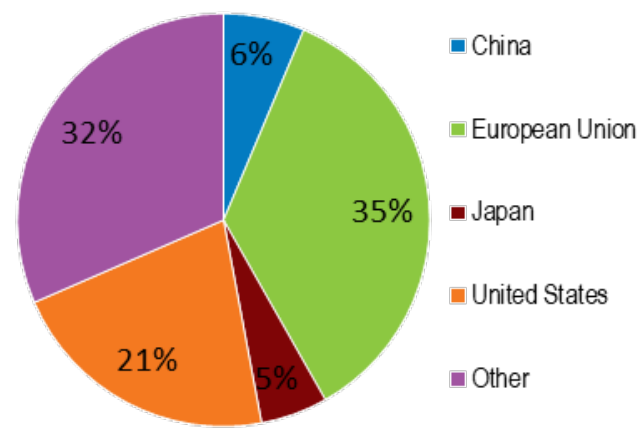

Note: Total overseas direct investment stock.

Source: CEIC and OECD Globalisation database, http://dx.doi.org/10.1787/888932707420.

Figure 3. China's relative importance as an investor increased sharply over the past decade

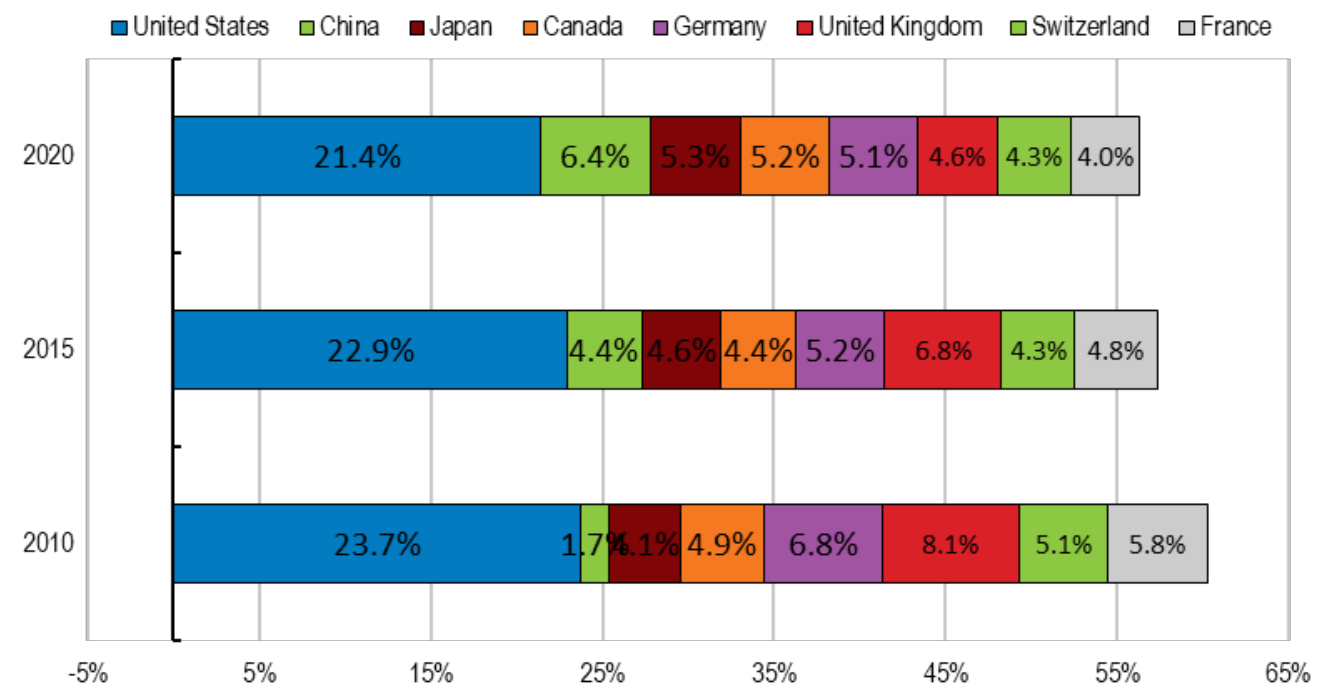

Note: Total overseas direct investment stock.

Source: OECD Globalisation database, http://dx.doi.org/10.1787/888932707420.

7. In comparison, the cumulated value of overseas greenfield investment projects and merger and acquisition deals was roughly USD 1.5 trillion in mid-2018, the latter exceeding the former by a large margin (Figure 4). It should be noted, however, that this figure is a simple cumulated value of overseas greenfield projects and M\&A deals with at least $10 \%$ of Chinese ownership. Also, the project or deal value in several greenfield projects or M\&A deals was not disclosed, making it impossible to take them into account. For the greenfield investment projects, the FDI Markets database and for the M\&A deals, the Dealogic database were used. These are considered the most complete available databases. Mirror data, if there were available for all China's investment destination countries, would also likely provide similar results. 
Some OECD member countries provide long historical series on China's investment position in their country, such as for instance the US Bureau of Economic Analysis publishes annual investment position data for investors in the United States since the 1980s, but at a less granular industry level than shown in this paper ( 7 manufacturing and 7 non-manufacturing sectors versus 16 manufacturing and 18 nonmanufacturing used here). The China Global Investment Tracker by the American Enterprise Institute and Heritage Foundation also tracks China's overseas investments and is free of charge, but it is less complete compared to the data used in this paper. In the databases used here, the originator is the country where the headquarters of the company that makes the greenfield investment, or of the acquirer in the case of M\&As, is registered. This "headquarter effect" can result in large investment attributed to small countries where many headquarters are registered such as the Netherlands.

8. When looking at the flows, the average sizes of both M\&A deals and greenfield projects increased till 2008, when they declined somewhat (Figure 5). While the average size of greenfield investments remained between USD 50 million and USD 100 million thereafter, the average deal size jumped to USD 286 million in 2017. As for overall trends, in 2017, new greenfield investments shrank, while M\&As continued unabated. The trends in M\&A deals based on the Dealogic database and the Ministry of Commerce's (MOFCOM's) data on China's M\&As via direct investment (flows) are roughly in line. In most years over the past decade, the deal-based data were roughly USD 10 billion above the official figures, though this meant a difference of a third in the earlier years. In 2017, the difference grew to USD 60 billion or roughly $50 \%$. This large difference may, at least partly, be attributed to financing of M\&As by overseas affiliates or overseas borrowing (i.e. not directly from China), which does not count as ODI according to Chinese official statistics.

Figure 4. Mergers and acquisitions have been a more important way of outward direct investment than greenfield

Outward direct investment stocks

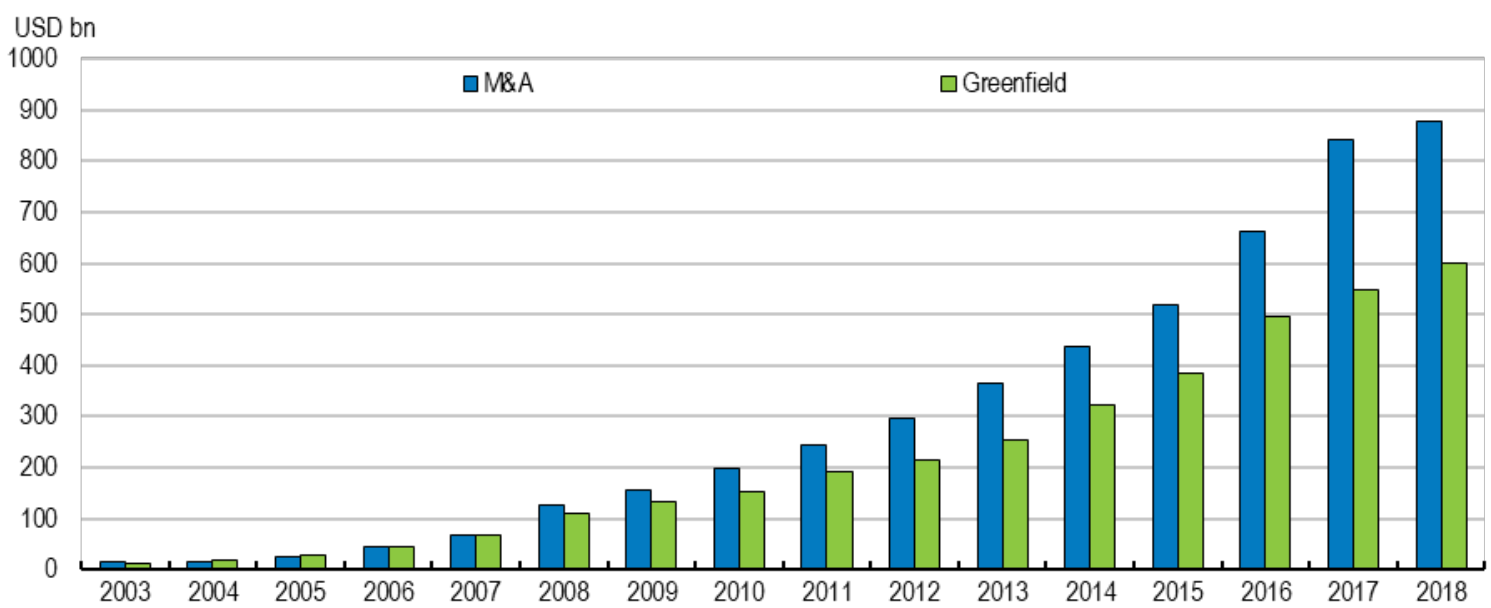

Note: Outward direct investment stocks are calculated by cumulating deal values of mergers and acquisitions and of greenfield investment values over time. Data series start in 1997 for mergers and acquisitions and in 2003 for greenfield investment projects. 2018 data are as of endJune 2018.

Source: Authors' calculations using the FDI Markets and Dealogic database. 
Figure 5. M\&A deals have increased while greenfield projects decreased in size in 2017

A. M\&A deals

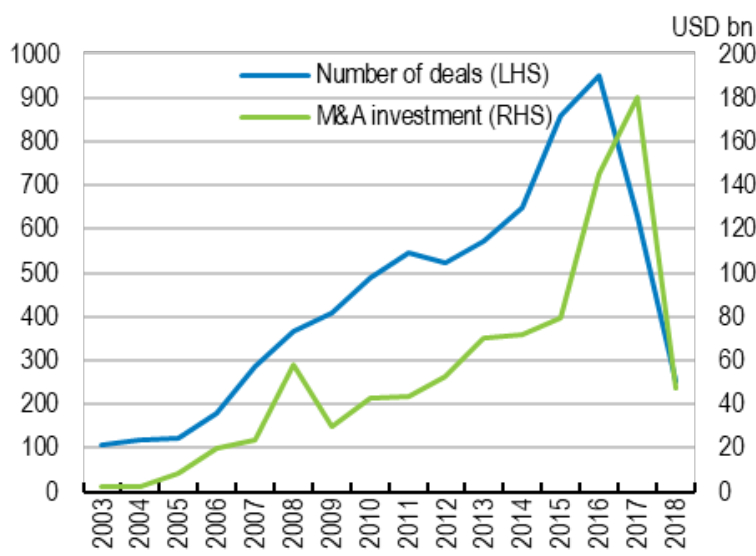

B. Greenfield projects

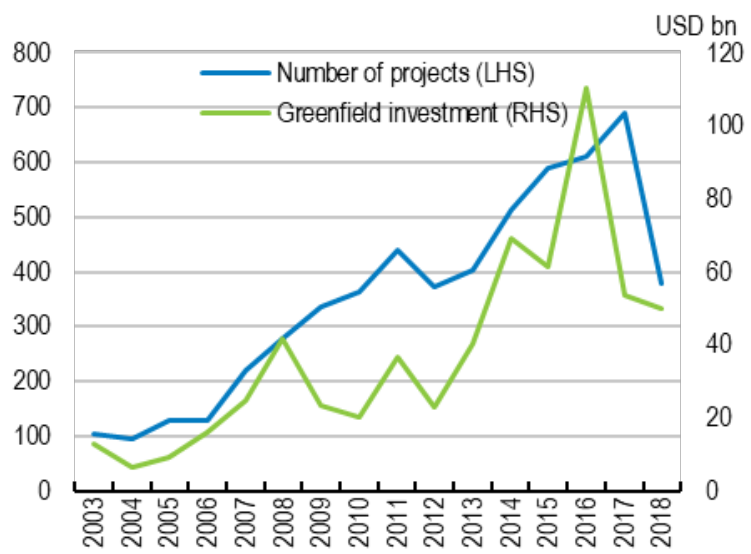

Note: The charts depict investment flows. 2018 data are as of end-June 2018.

Source: FDI Markets and Dealogic database.

9. According to Chinese official statistics, as of 2018 , roughly $58 \%$ of non-financial ODI stock is registered under central firms or units with the remaining compiled at the local level. Among local firms and units, not surprisingly, most investors are located in coastal provinces and municipalities (Figure 6) with Guangdong representing 10\% of China's ODI stock. Shanghai, Beijing, Zhejiang, Shandong and Jiangsu also comprise over $2 \%$ each. These local figures do not include the financial sector as the State Administration Foreign Exchange compiles those data, not the local bodies of the Ministry of Commerce. By 2019, the top ten provinces altogether accounted for over $82 \%$ of China's non-financial outward investment stock at the local level (i.e. not including central firms or units) (Ministry of Commerce, National Bureau of Statistics and State Administration for Foreign Exchange, 2020). 
12 | $\operatorname{ECO} / \mathrm{WKP}(2021) 36$

Figure 6. Most Chinese ODI comes from coastal provinces and municipalities

Non-financial outward direct investment stock, 2018

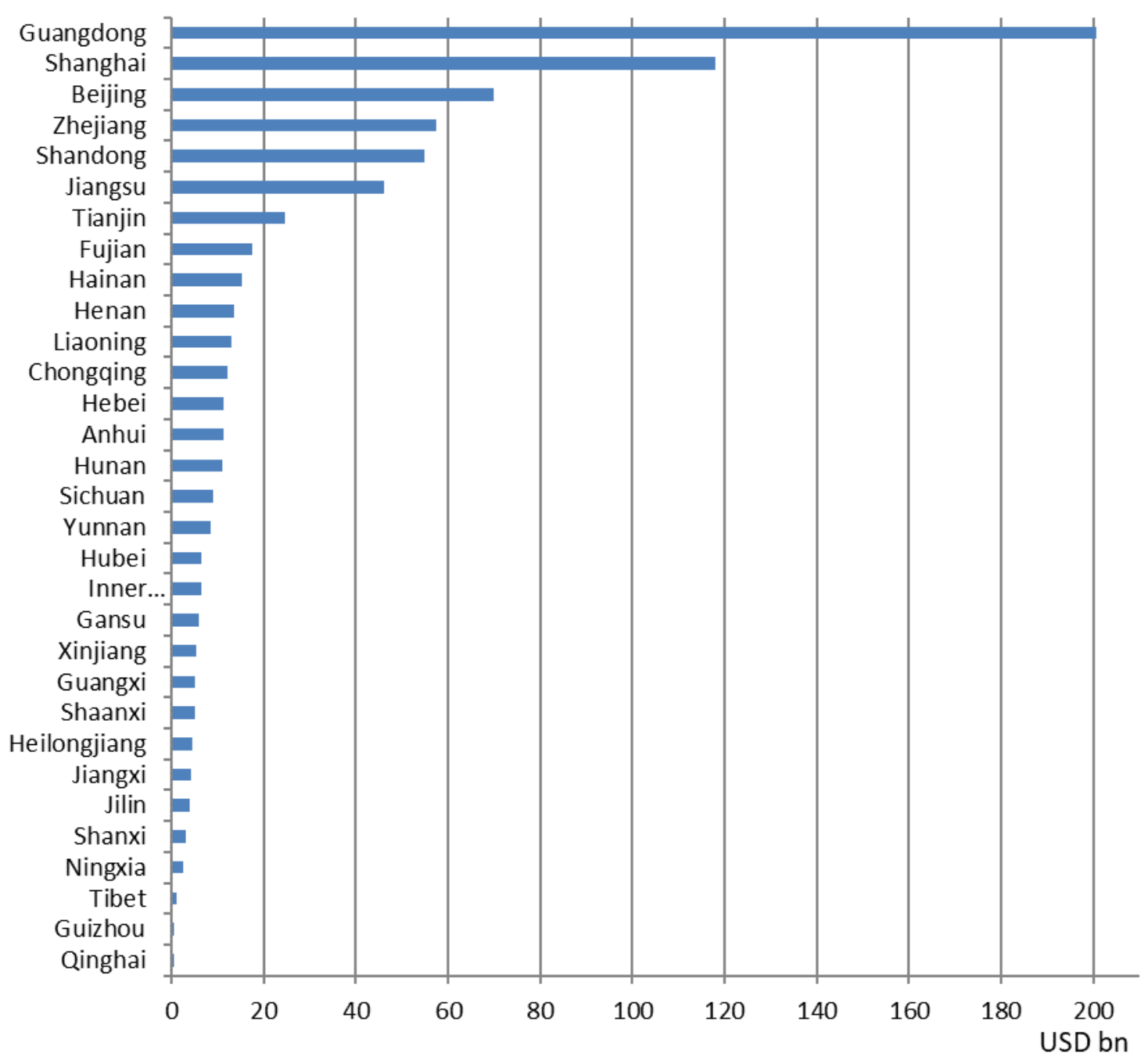

Note: The chart only includes investment registered at the local level and does not include investment by central enterprises and units. Source: Ministry of Commerce (2019), 2018 Statistical Bulletin of China's Outward Foreign Direct Investment. 
10. Listed firms closed more deals in the past decade or so, though before that, non-listed private firms ranked first for a few years (Figure 7). In the first half of 2018, the number of deals shrank somewhat. This may be related to more rigorous oversight and uncertainty amid slowing of the economy. In terms of deal value, non-listed SOEs ranked first in most years except 2013, 2015 and 2016, when listed firms took over the leading place.

\section{Figure 7. Listed firms have been the major acquirers}

Number and size of deals by acquirer's type

A. Number of M\&A by acquiror's public status

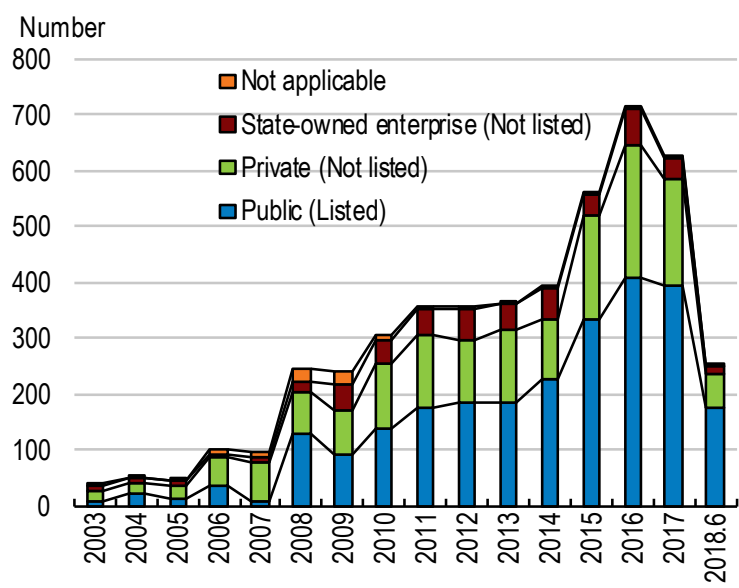

B. Deal value of M\&A by acquiror's public status

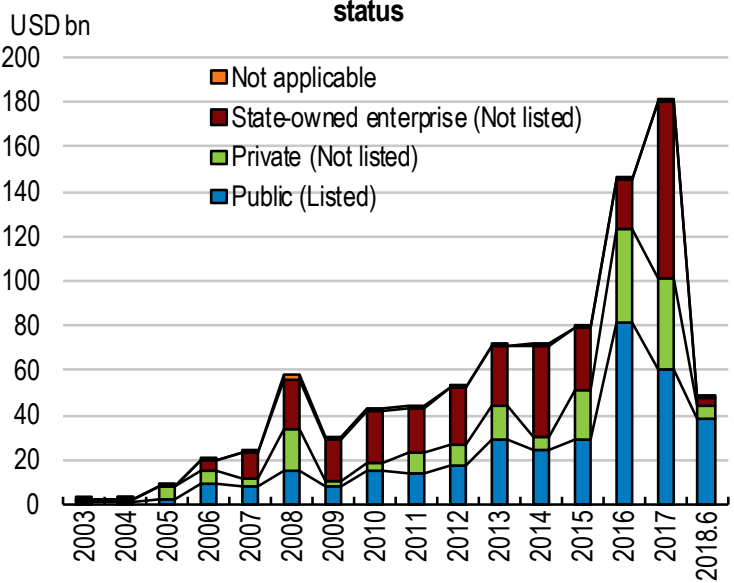

Note: The figure includes deals for which the acquirer's status is indicated. Public (listed) firms can be private firms or state-owned enterprises. Source: Dealogic database.

11. A major divergence between outward direct investment data compiled by the Ministry of Commerce and in other countries is that in the former case investment by foreign affiliates is not included. That is how China's largest ever foreign acquisition (of Syngenta in Switzerland by a Chinese company) is not fully showing up in the official numbers, as it was mainly financed from outside China (Scissors, 2018).

\section{The geographical dimension}

12. Major destinations of China's ODI include the United States with over $13 \%$ and Hong Kong, China with nearly 8\% share of the cumulated greenfield investment and M\&A deals as of 2017 (Figure 8). Australia, Brazil, the United Kingdom, Switzerland and Canada account for 4-5\% each, and Indonesia, India and Singapore over 2\% each. 
Figure 8. The United States is the major destination for China's ODI, followed by Hong Kong, China in 2017

Greenfield and M\&A deals, cumulated

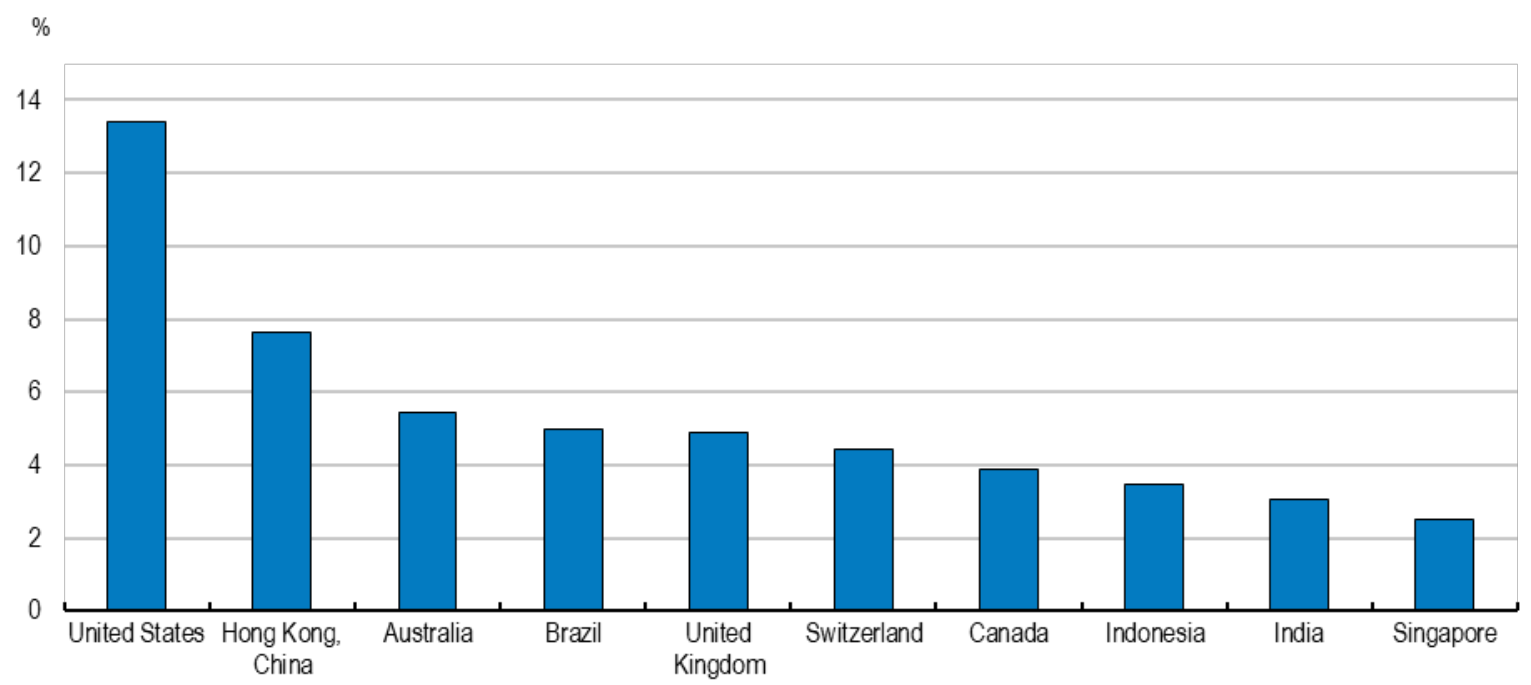

Note: Outward direct investment stocks are calculated by cumulating deal values of mergers and acquisitions and of greenfield investment values over time. Data series start in 1997 for mergers and acquisitions and in 2003 for greenfield investment projects.

Source: Authors' compilation based on the FDI Markets and Dealogic databases.

13. Many economies among the top 10 greenfield investment destinations are resource-rich economies such as Indonesia, Russia, Malaysia, Egypt, Brazil and Australia (Figure 9). As for M\&As, only advanced economies are among the top ten destinations, with the exception of Brazil.

Figure 9. The United States tops Chinese greenfield investment and M\&A destinations - based on greenfield project and M\&A deal data

A. Greenfield investment top 10 by destination, 2017

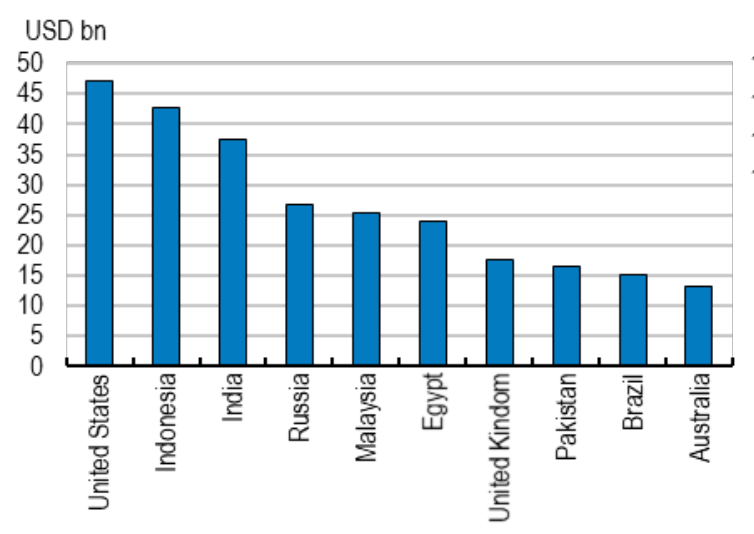

B. M\&A investment top 10 by destination, 2017

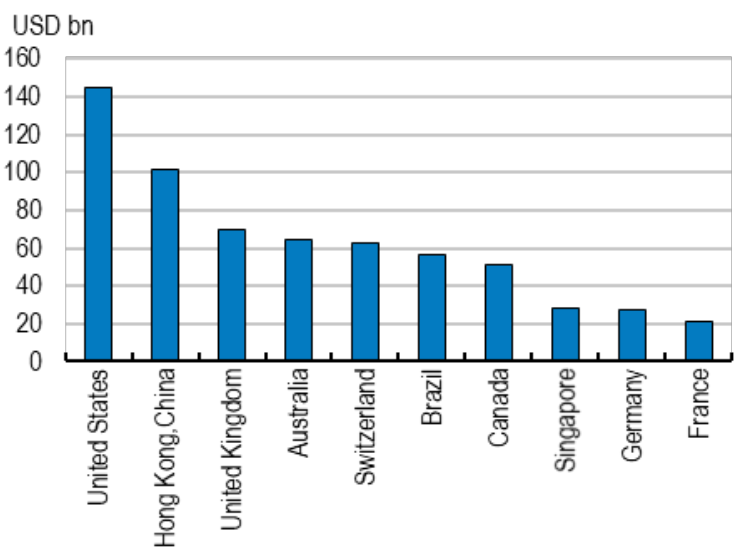

Note: Outward direct investment stocks are calculated by cumulating deal values of mergers and acquisitions and of greenfield investment values over time. Data series start in 1997 for mergers and acquisitions and in 2003 for greenfield investment projects.

Source: FDI Markets and Dealogic database. 
14. At the city level, New York City is the most favoured destination for Chinese greenfield investment, followed by Hong Kong, China, Singapore, Johannesburg and London (Figure 10). Some cities in resource-rich Malaysia, Indonesia, the Philippines, Saudi Arabia and Oman are also among the favoured destinations.

\section{Figure 10. Top 20 cities receiving Chinese greenfield investment}

Greenfield investment stock, 2017

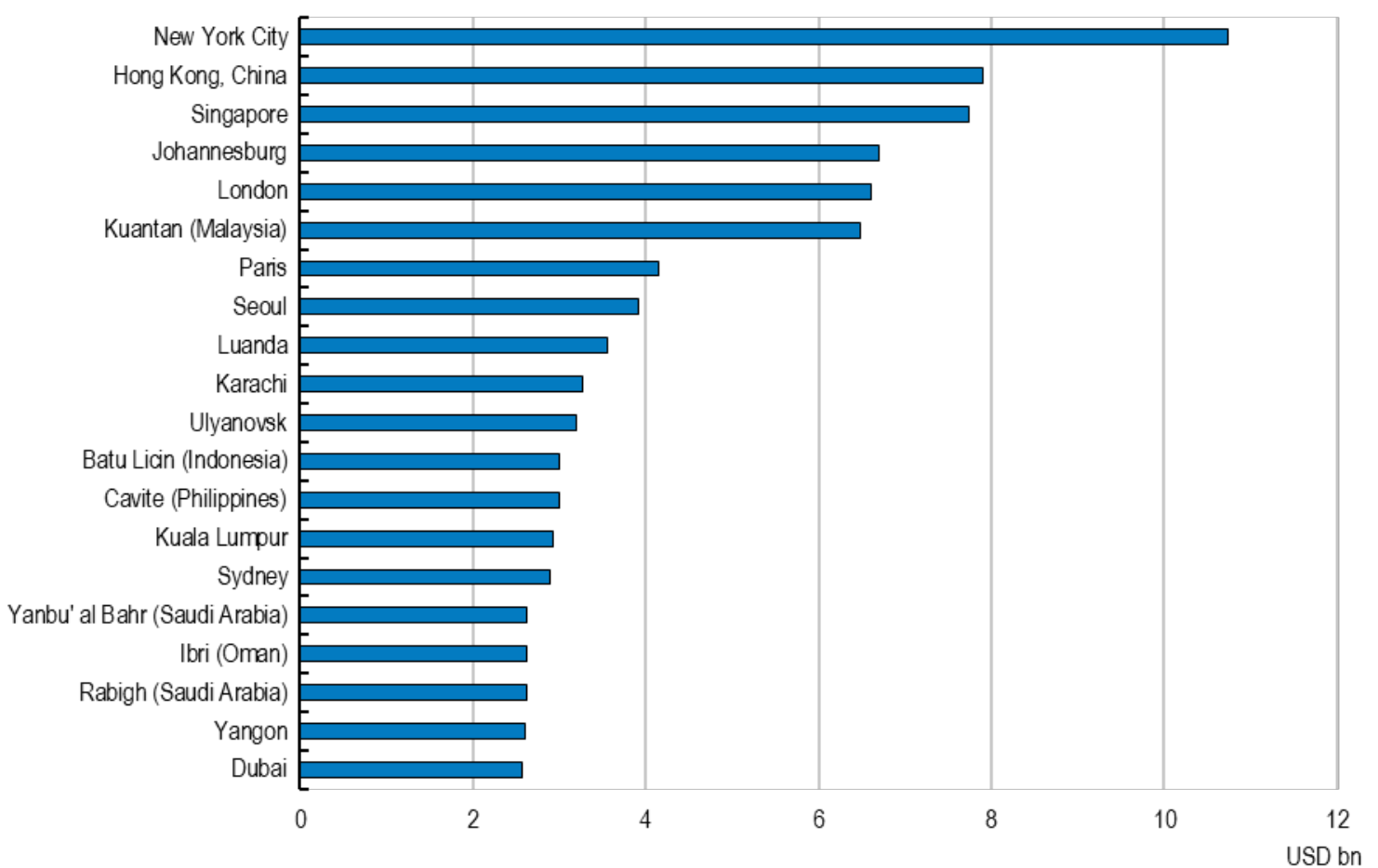

Note: The chart only includes projects for which the destination city is indicated, which is roughly $70 \%$ of the cumulated projects. Outward direct investment stocks are calculated by cumulating greenfield investment over time. Data series start in 2003.

Source: FDI Markets database.

15. It is also worth looking at how important China as an investor is for other countries/economies. Table 1 ranks countries/economies by whether China is number 1-5 among their investors, then by the share of Chinese ODI (Table 1). As of 2018, China is the most important investor in Tajikistan, Cambodia, the Kyrgyz Republic and Sri Lanka; in Tajikistan it commands 50\% of FDI (up from 44\% in 2017). China's share in Niger is similarly high at 42\%, though China is only Niger's No. 2 investor. Among OECD countries, China ranks among the top five investors only in two countries. $4 \%$ of Australia's FDI comes from China, while Israel's $3 \%$. In fact, China should be the top or among the top few investors for many more countries, in particular in Africa, but those countries do not report to the CDIS database and therefore are not included in the below table. Major changes in 2018 versus 2017 include China's becoming No. 2 investor in Bangladesh and No. 5 in Belarus in 2018. Neither of those countries had China among their top five investors in 2017. China's jump among Bangladesh' investors is related to large investment in the Bangladeshi power sector in 2018, while in Belarus it steadily boosted its investments, including in industrial parks and the construction sector. China's share increased in 2018 in several countries/economies where China was already among the top five investors in 2017, but it dropped in Myanmar from 33\% in 2017 to $25 \%$ in 2018 . This drop is related to Singapore's large-scale investment in Myanmar's telecommunications sector in that year (and in other industries). 


\section{Table 1. Many economies relay heavily on China for foreign investment}

List of economies where China is among the top five investors, 2018

\begin{tabular}{|c|c|c|c|c|}
\hline & $\begin{array}{l}\text { Total inward direct investment stock } \\
\text { (USD billion) }\end{array}$ & $\begin{array}{l}\text { China's investment stock (USD } \\
\text { billion) }\end{array}$ & $\begin{array}{c}\text { China's share } \\
(\%)\end{array}$ & $\begin{array}{l}\text { China's } \\
\text { ranking }\end{array}$ \\
\hline Tajikistan & 2.86 & 1.44 & 50 & No. 1 \\
\hline Cambodia & 23.25 & 6.79 & 29 & No. 1 \\
\hline Kyrgyz Republic & 4.92 & 1.35 & 27 & No. 1 \\
\hline Sri Lanka & 12.76 & 2.13 & 17 & No. 1 \\
\hline Niger & 6.06 & 2.56 & 42 & No. 2 \\
\hline Hong Kong, China & 1706.79 & 466.53 & 27 & No. 2 \\
\hline Myanmar & 27.33 & 6.93 & 25 & No. 2 \\
\hline Mongolia & 20.22 & 4.92 & 24 & No. 2 \\
\hline Zambia & 25.78 & 3.35 & 13 & No. 2 \\
\hline Nepal & 1.47 & 0.15 & 10 & No. 2 \\
\hline Bangladesh & 16.03 & 1.44 & 9 & No. 2 \\
\hline Macao, China & 34.91 & 6.24 & 18 & No. 3 \\
\hline Kazakhstan & 149.01 & 8.27 & 6 & No. 4 \\
\hline Israel & 145.35 & 4.26 & 3 & No. 4 \\
\hline Australia & 682.87 & 28.31 & 4 & No. 5 \\
\hline Belarus & 13.03 & 0.37 & 3 & No. 5 \\
\hline
\end{tabular}

Note: 2018 data in the IMF CDIS database are available for 108 economies. The table shows those where China is among the top five foreign direct investors and countries are ranked by China's ranking among foreign investors, then by China's share.

Source: Authors' compilation from the IMF Coordinated Direct Investment Survey (CDIS) database.

\section{The sectoral dimension}

16. If using the project-level greenfield and the deal-level M\&A data to compile indicative ODI stocks by cumulating those values, China's manufacturing ODI stock is comparable to that of Japan (Figure 14). While this magnitude is significantly above what official data indicate, the pace of manufacturing ODI expansion appears less rapid by this measure. Instead of a five-fold increase of manufacturing ODI observed in official data over the past five years, this new compilation indicates a less-than three-fold increase (Figure 11). Official ODI data published by the Ministry of Commerce do not disclose investment in manufacturing sub-industries, but the compiled bottom-up database indicates that resource-based industries have been major targets of Chinese manufacturing ODI, with non-metallic and metal products and chemicals making up a fifth each, followed by petroleum and coking at $17 \%$. 
Figure 11. China's manufacturing ODI grew three-fold over the past five years and is concentrated in resource-based industries

Based on greenfield project and M\&A deal data

\section{A. ODI stock in manufacturing}

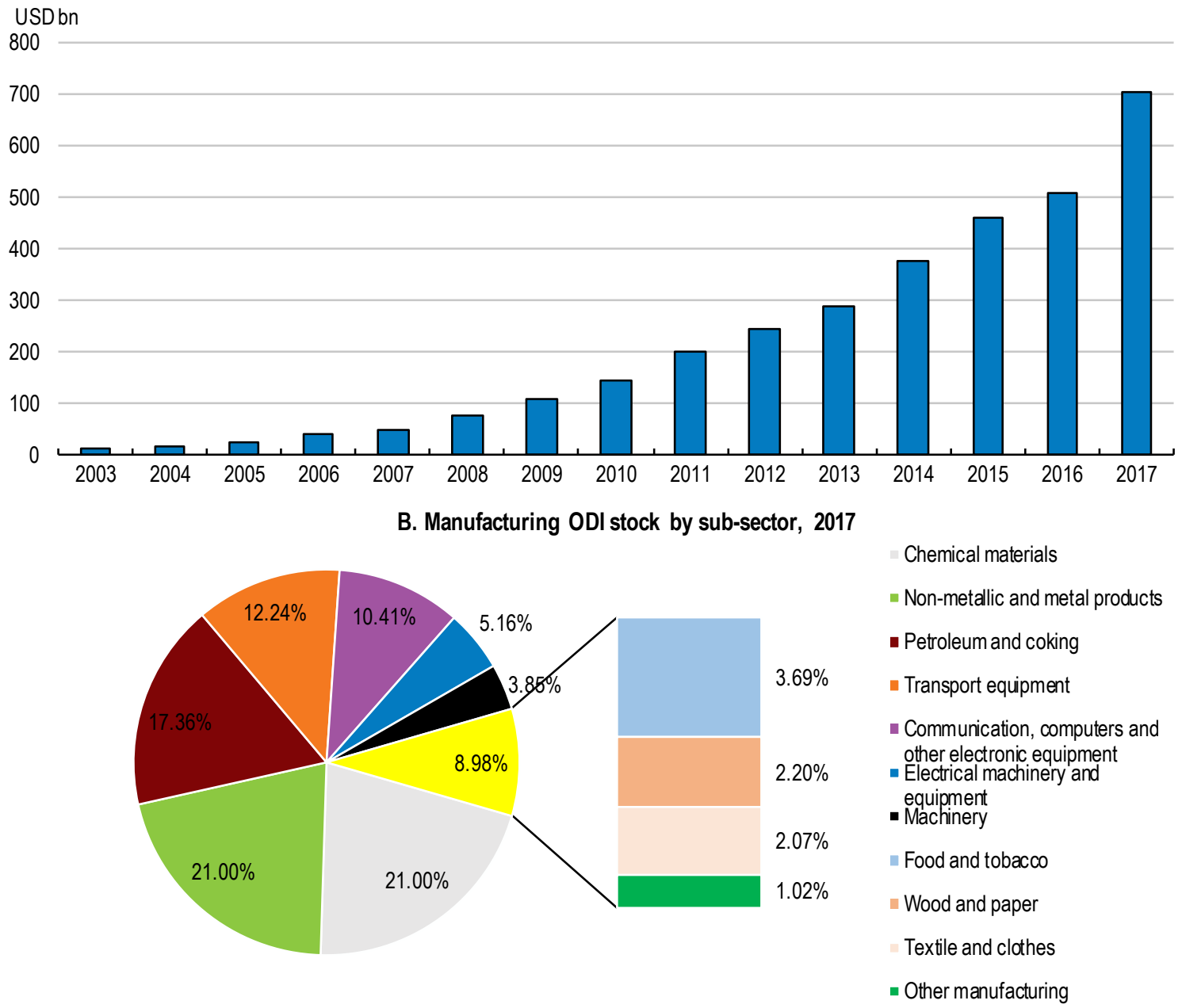

Note: Outward direct investment stocks are calculated by cumulating deal values of mergers and acquisitions and of greenfield investment values over time. Data series start in 1997 for mergers and acquisitions and in 2003 for greenfield investment projects.

Source: FDI Markets and Dealogic database.

17. According to the newly compiled data, manufacturing is a more important target of Chinese ODI than services, commanding 39\% of the total stock in 2017 (Figure 12). In contrast, services ODI makes up less than a third of the total and among its sub-sectors, finance's share is nearly half. Moreover, leasing and business services, which comprised nearly a half of services ODI according to official data, by this new compilation, command only a mere $5 \%$ share. While such a bottom-up compilation has many caveats, including the incompleteness of the data at the project and deal level, missing project and deal values and ignoring other forms of ODI, it provides information on the industries where the greenfield investments were made or where the acquired firm is classified. 
Figure 12. Most ODI goes to manufacturing and finance

Based on greenfield project and M\&A deal data

\section{A. ODI stock by major industries}

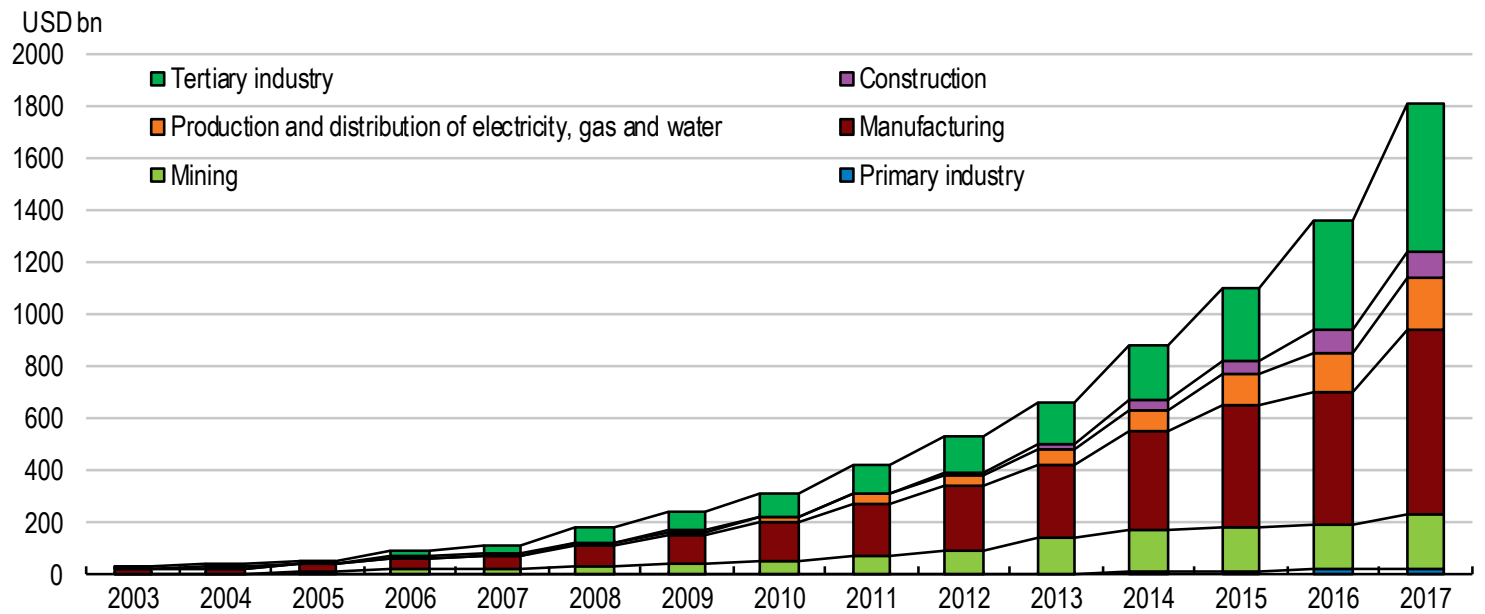

B. ODI stock by major service industries

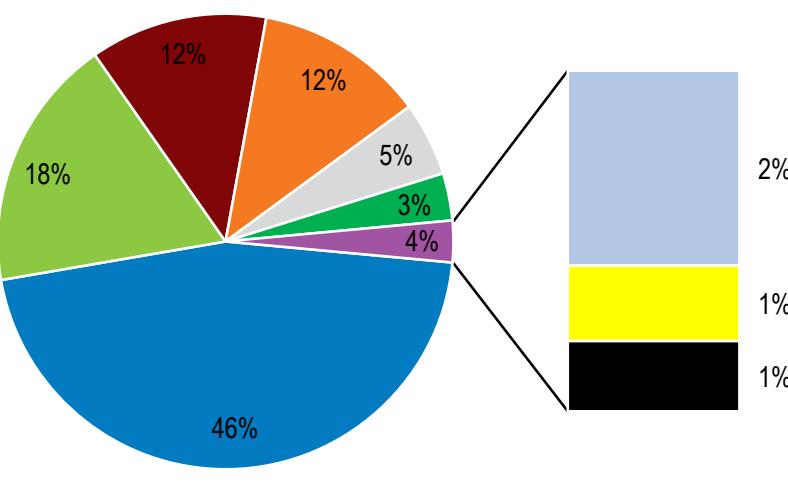

- Financial intermediation

- Real estate

- Traffic, transport, storage and post

- Information transmission, computer

services and software

- Leasing and business services

- Other services

-Wholesale and retail trade

Scientific research, technical services and geologic prospecting

- Services to households and other services

Note: Outward direct investment stocks are calculated by cumulating deal values of mergers and acquisitions and of greenfield investment values over time. Data series start in 1997 for mergers and acquisitions and in 2003 for greenfield investment projects.

Source: FDI Markets and Dealogic database.

18. Chinese greenfield investors cumulatively created 1.3 million jobs around the world by 2017 (Figure 13). Over two-thirds of those jobs are in manufacturing, a sixth in construction and over a tenth in other tertiary services. Within the manufacturing sector, over $30 \%$ of the newly created employment or 260000 jobs are in transport equipment manufacturing. Within services, the same share is created in transport and storage, though in absolute terms that equals 28000 jobs. 
Figure 13. Overseas job creation by Chinese affiliates, 2017

Based on greenfield project data

\section{A. Cumulated overseas job creation by major industries}

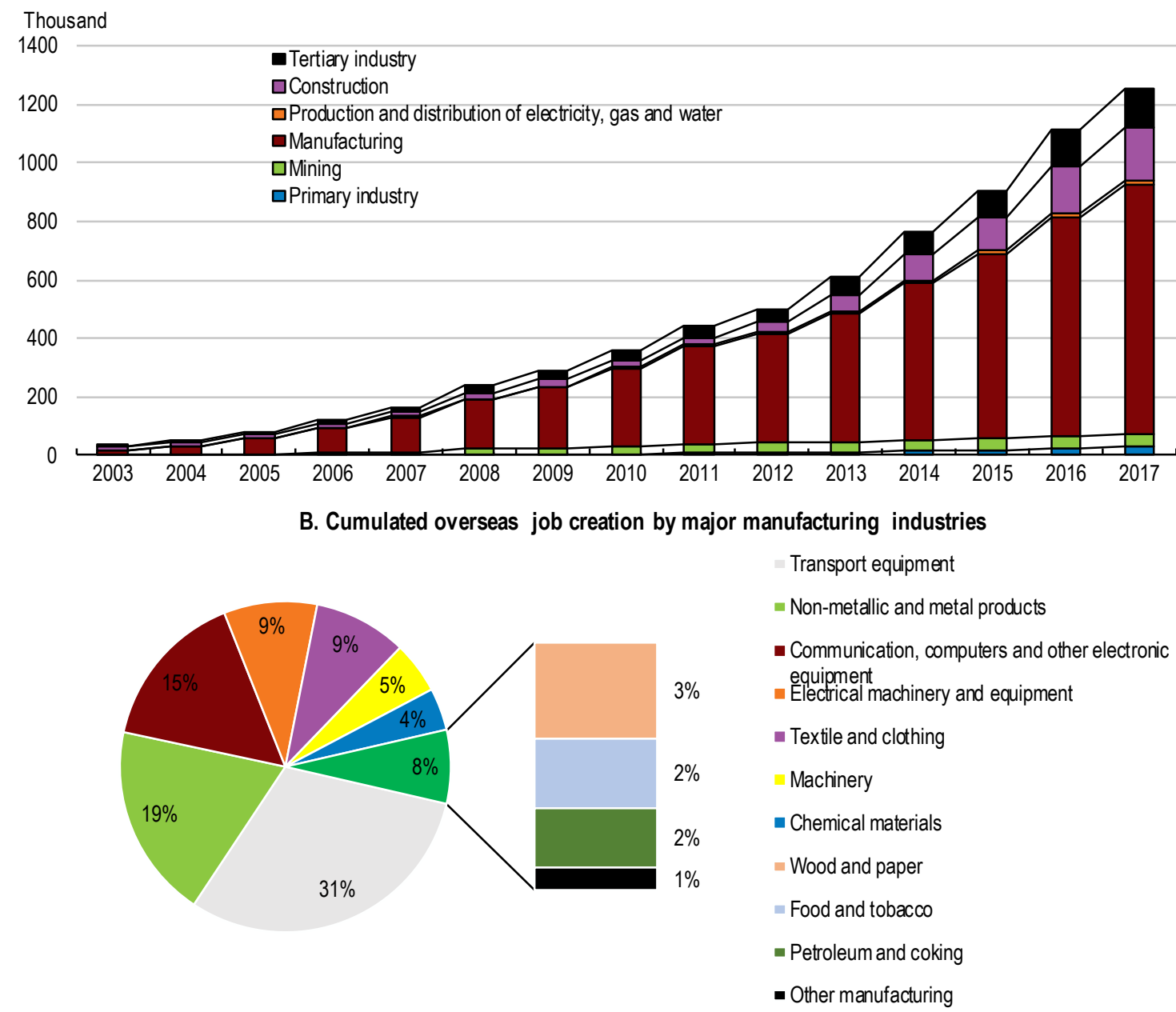

C. Cumulated overseas job creation by major services industries

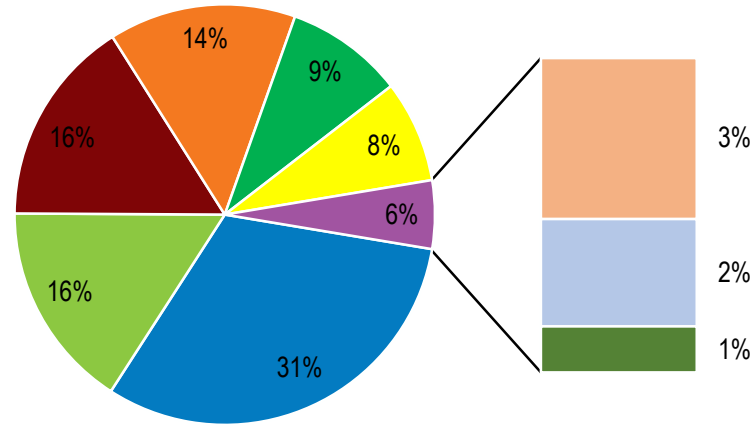

- Traffic, transport, storage and post

- Information transmission, computer services and software

- Real estate

— Financial intermediation

Wholesale and retail trades

Other services

- Leasing and business services

- Services to households and other services

- Scientific research, technical service and geologic prospecting

Note: Industry classification follows the Chinese official one, where construction and utilities belong to the secondary industry. Source: Authors' compilation based on the FDI Markets database. 
19. China's overall ODI stock is comparable to that of Japan, but in some sectors China's presence is even stronger than in overall ODI. In manufacturing, for instance, in 2017 China's ODI stock exceeded Japan's and is approaching that of the United States (Figure 14). In mining, among OECD members, only the Netherlands has a higher ODI stock than China (Figure 15). In services (not including construction and utilities), China's ranking is not that prominent, there are nine OECD countries with higher ODI stocks. In some services, however, China is world leader. Those include construction services, utilities and traffic, transport, storage and postal services (Figure 16). China is also a big investor in IT services, but less so in commerce and finance.

\section{Figure 14. China's manufacturing ODI stock has exceeded Japan's}

ODI stock, 2017

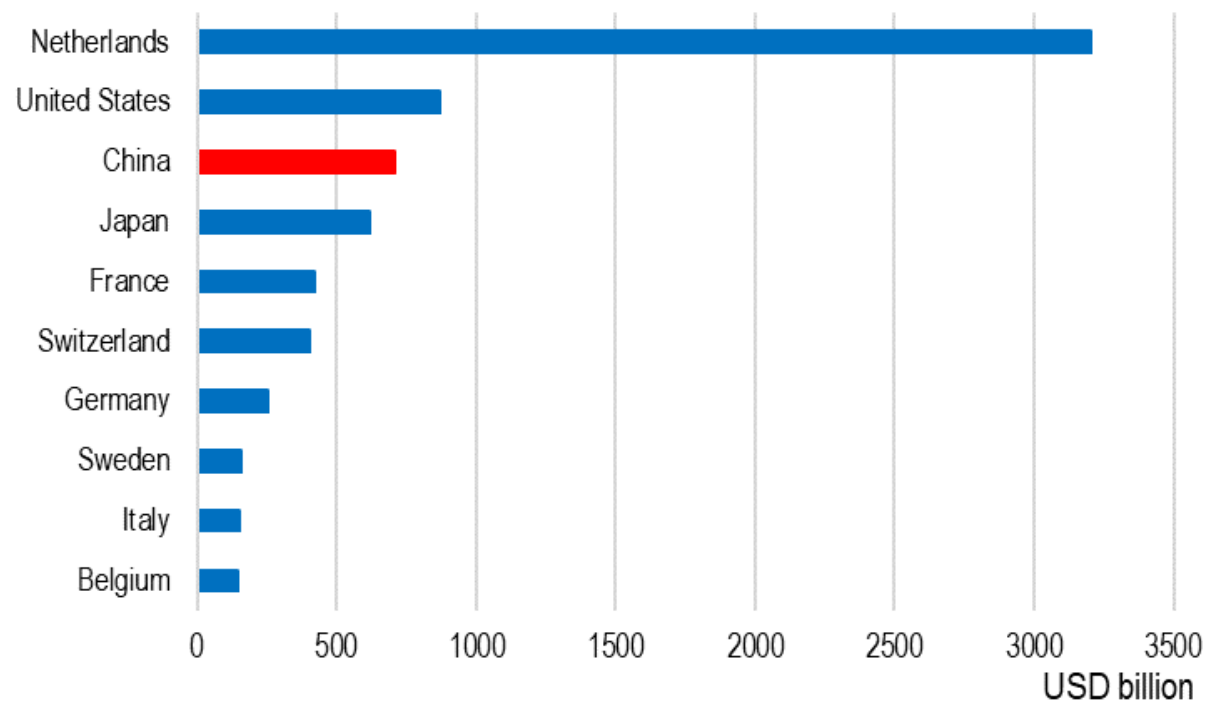

Note: For China, outward direct investment stocks are calculated by cumulating deal values of mergers and acquisitions and of greenfield investment values over time. Data series start in 1997 for mergers and acquisitions and in 2003 for greenfield investment projects. The United Kingdom has not published 2017 sector-level data in the OECD Globalisation Database at the time of finalising this paper, therefore it is not included in the charts.

Source: OECD Globalisation database, http://dx.doi.org/10.1787/888932707420 and FDI Markets and Dealogic databases. 
Figure 15. China is the leading investor in construction services and utilities, but not in services, in general

ODI stock, 2017

\section{A. Mining}

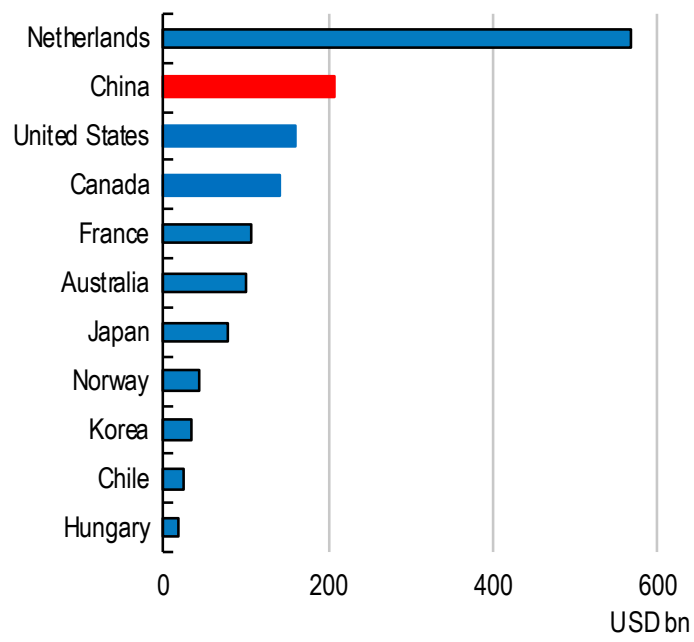

C. Construction

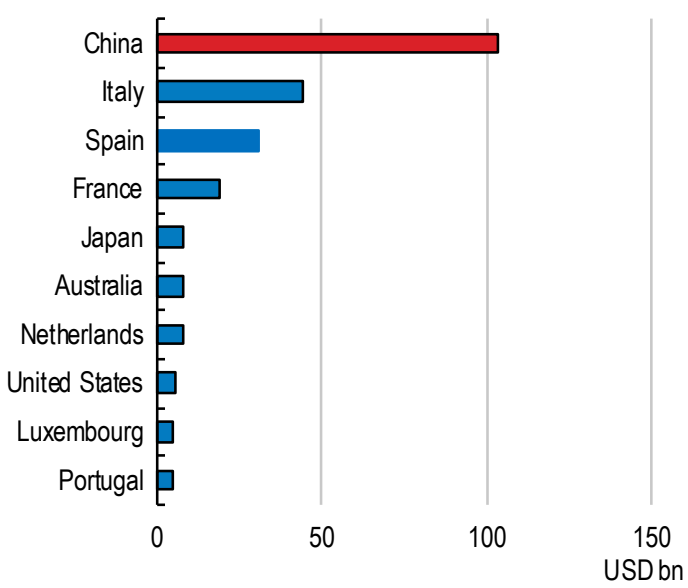

B. Services

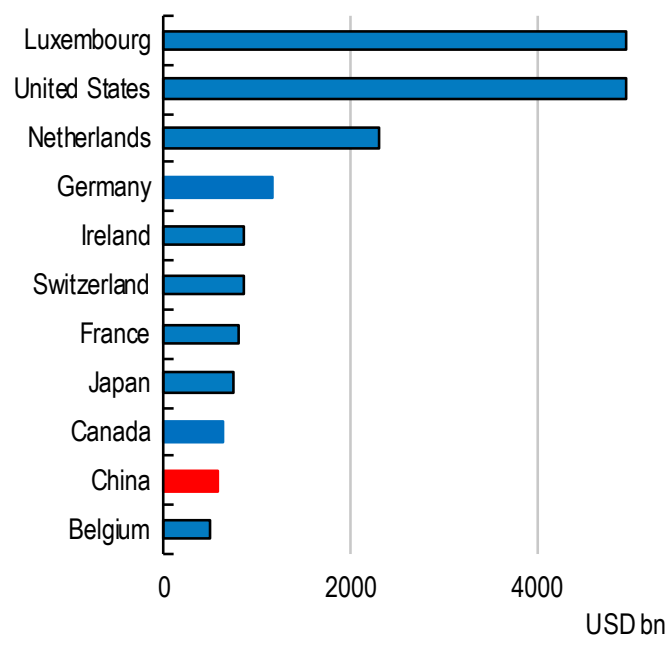

D. Production and distribution of electricity, gas and water

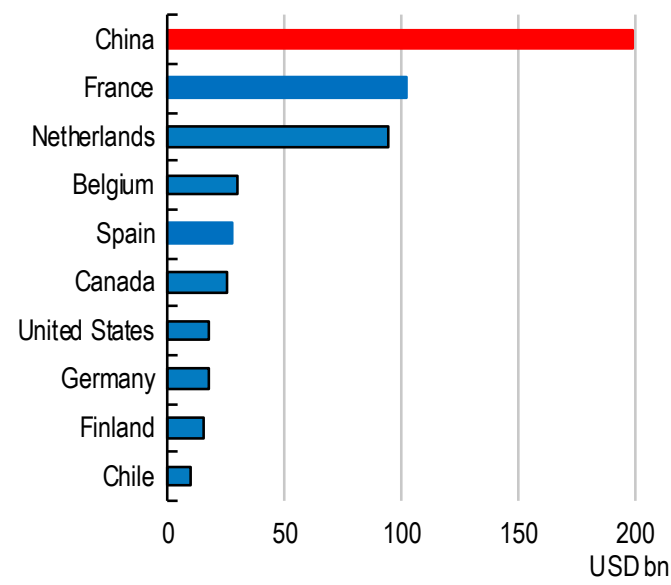

Note: For China, outward direct investment stocks are calculated by cumulating deal values of mergers and acquisitions and of greenfield investment values over time. Data series start in 1997 for mergers and acquisitions and in 2003 for greenfield investment projects. Industry classification follows the Chinese official one, where construction and utilities are not included in services. The United Kingdom has not published 2017 sector-level data in the OECD Globalisation Database at the time of finalising this paper, therefore it is not included in the charts. Source: OECD Globalisation database, http://dx.doi.org/10.1787/888932707420, FDI Markets and Dealogic databases. 


\section{Figure 16. China is world leader in ODI stock in transportation and related services, but invests} little in commerce and finance

ODI stock, 2017

A. Wholesale and retail trade

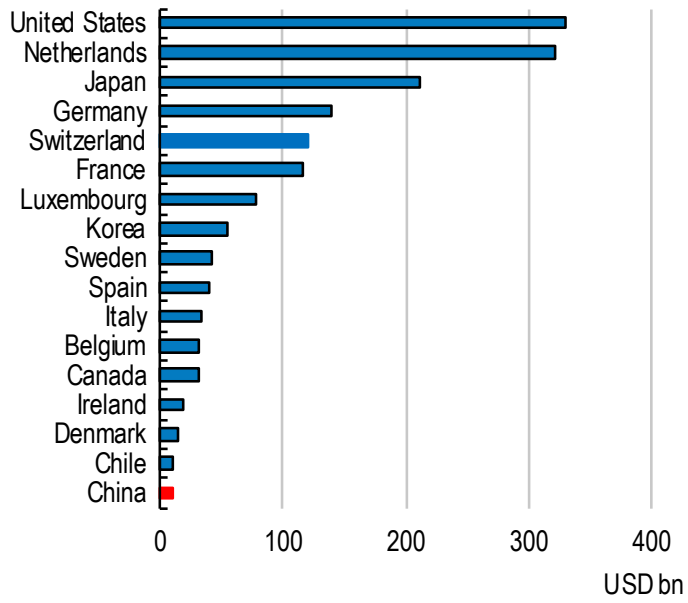

C. Information transmission, computer services and software

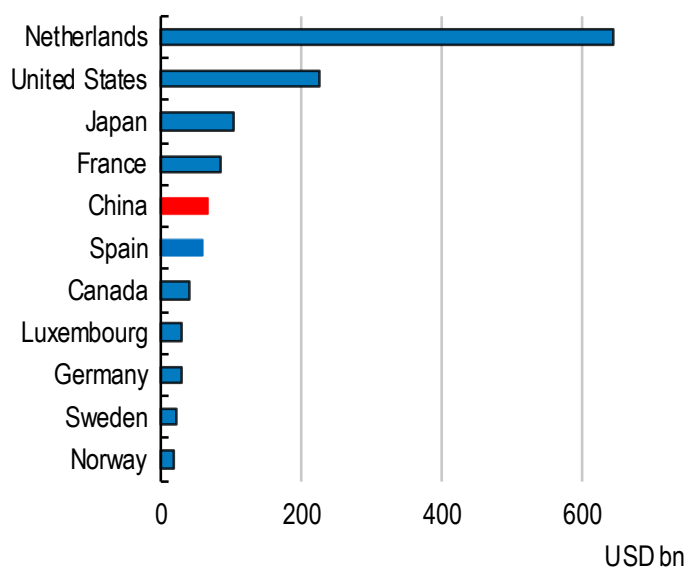

B. Traffic, transport, storage and post

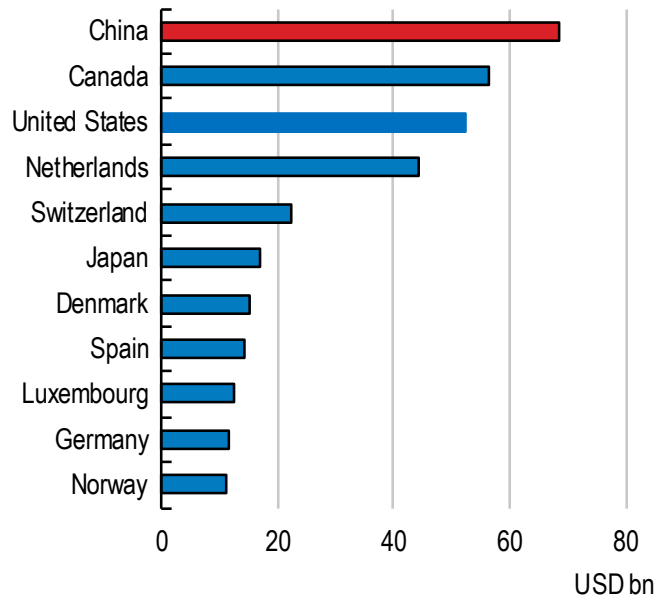

D. Financial intermediation

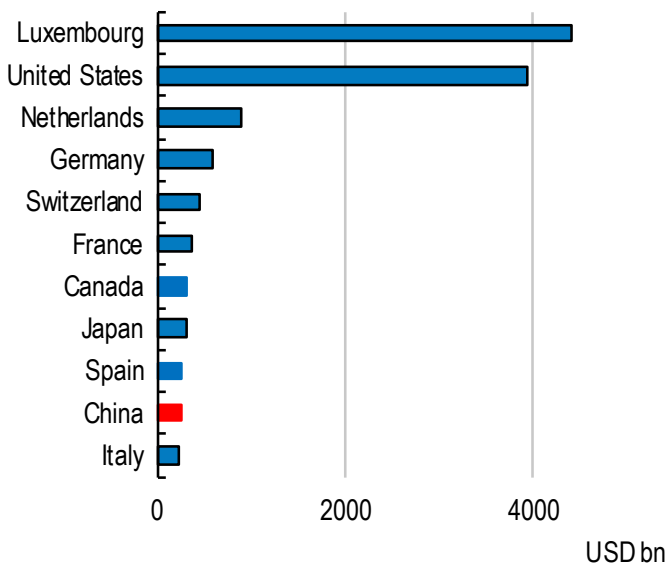

Note: For China, outward direct investment stocks are calculated by cumulating deal values of mergers and acquisitions and of greenfield investment values over time. Data series start in 1997 for mergers and acquisitions and in 2003 for greenfield investment projects. The United Kingdom has not published 2017 sector-level data in the OECD Globalisation Database at the time of finalising this paper, therefore it is not included in the charts.

Source: OECD Globalisation database, http://dx.doi.org/10.1787/888932707420, FDI Markets and Dealogic databases.

\section{The sectoral dimension in major destinations}

20. The compiled database shows that the six economic entities for which China publishes bilateral data by industry (i.e. the United States, Hong Kong, China, the European Union, the ASEAN, Australia and Russia) indeed comprise most Chinese ODI in finance and IT services (Figure 17). In real estate and transportation, in contrast, the six economies jointly command only a half or less of Chinese ODI. Hong Kong, China's share is small in contrast to its high share by the official data, suggesting ODI, in particular in real estate and transportation services, transits the city and ends up in a third destination other than those six entities. In greenfield real estate, important destinations are Egypt, South Africa and Angola, all with higher shares than any of the six economic entities. In real estate M\&A, the United States, the European Union and Hong Kong, China are the major destinations. In greenfield transportation services 
investment, only Hong Kong, China and the ASEAN among the six economic entities are included in the top five destinations, preceded by Mozambique, Algeria and Turkmenistan. In transportation services M\&As, in addition to the six economic entities, Switzerland, Bermuda, Sri Lanka and Turkey are also important destinations. In manufacturing and mining, the share of the six economic entities is less than a third. For greenfield, the BRIICS economies are major destinations besides the six economic entities. For M\&As, Switzerland, Israel, Peru, the ASEAN, Australia, Singapore and Japan make it to the top ten Chinese manufacturing ODI destinations in addition to the United States, the European Union and Hong Kong, China.

\section{Figure 17. Chinese ODI in advanced economies goes mainly to manufacturing and finance}

2017

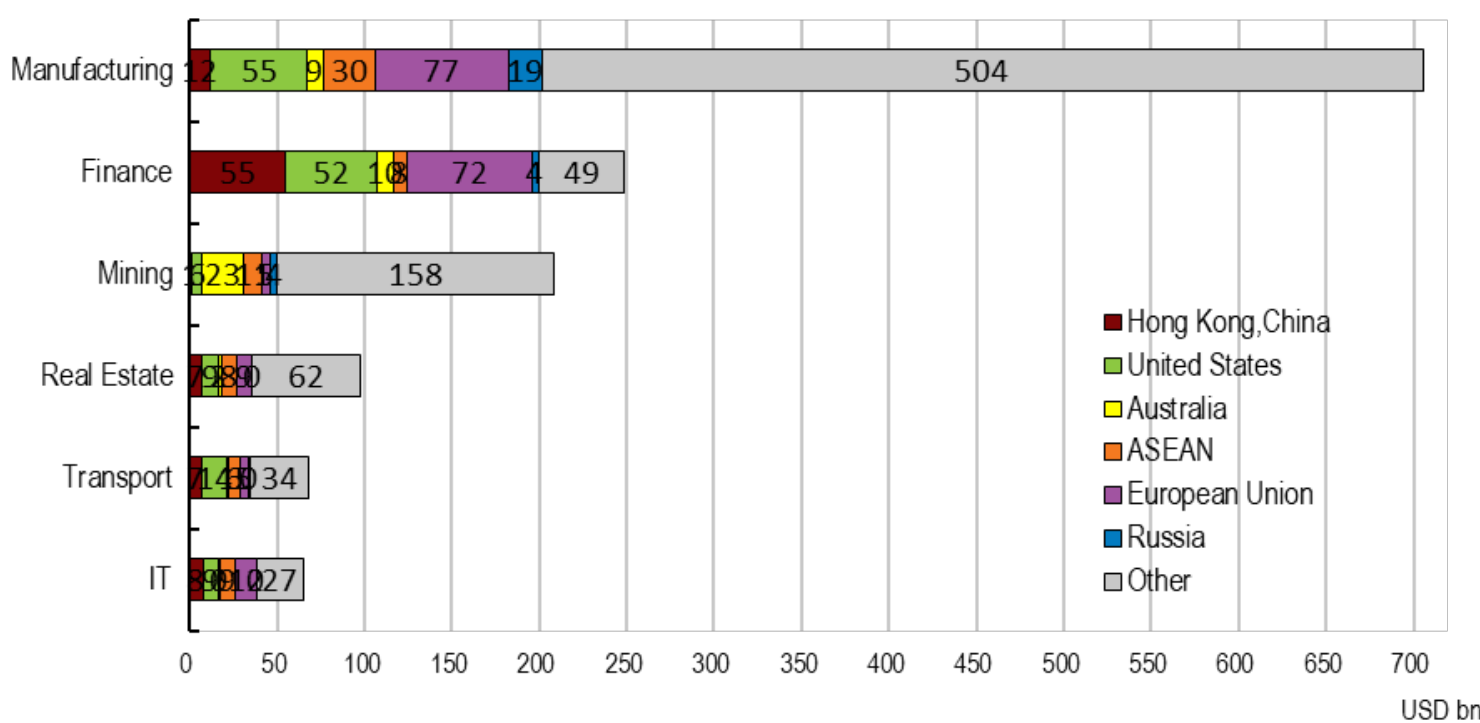

Note: Outward direct investment stocks are calculated by cumulating deal values of mergers and acquisitions and of greenfield investment values over time. Data series start in 1997 for mergers and acquisitions and in 2003 for greenfield investment projects.

Source: FDI Markets and Dealogic databases.

\section{The impact of China's overseas direct investment on its domestic employment}

21. Recently there have been concerns, in particular in some Eastern Chinese provinces where the private sector is vibrant, that soaring private sector investment overseas may be related to moving factories overseas attracted by lower wages, and hence may be at the expense of domestic employment. This section tests empirically whether overseas investment has a negative impact on domestic employment.

\section{Gauging the impact of ODI on domestic employment and description of data}

22. In the international literature, there is a large collection of studies testing the substitutability of parent company and affiliate employment. In contrast, empirical research examining the impact of outsourcing through overseas foreign direct investment on domestic employment in China is scarce, notwithstanding that China has emerged as a major international investor. The scarcity of research in this field is largely owing to the lack of readily available data, as China does not publish Foreign Affiliates Trade Statistics (FATS), unlike many other major international investor countries. This paper contributes to filling this gap. It uses foreign direct investment to capture overseas production as that is the only data available, although internationally comparable data only after some manipulation. 
23. Among the few studies focusing on the impact of China's overseas direct investment on domestic employment, Li et al. (2016) found that overseas direct investment affects domestic employment positively. They use firm-level data of industrial firms (including manufacturers, utilities and mining firms) over 200013 and capture ODI by a dummy variable (i.e. whether the firm has invested overseas or not). Regardless of firm ownership, they found that overseas investment and domestic employment are positively associated. Song et al. (2017) also showed a positive effect of overseas direct investment on domestic employment using a province-level panel over 2004-14, with the effect decreasing as moving from East to West.

24. Notwithstanding its large size, the existing international literature does not provide a clear-cut suggestion on the direction of the impact of overseas production on domestic employment. The results very often vary by the destination country or the sector. To gauge the impact of overseas direct investment on domestic employment in China, the paper estimates a standard labour demand function augmented by overseas direct investment and including the interaction terms of ODI with the employment and the wage variables, respectively, as below in Equation (1):

$$
\begin{aligned}
& \Delta \operatorname{lnL}_{i, t}=a_{0}+a_{1} \Delta \operatorname{lnY}_{i, t}+a_{2} \Delta \operatorname{lnRW}_{i, t}+\left(a_{4}+\gamma_{1} \operatorname{lnODI}_{i, t-1}\right)\left[\operatorname{lnL}_{i, t-1}+\left(\lambda_{1}+\gamma_{2} \operatorname{lnODI}_{i, t-1}\right) \ln Y_{i, t-1}+\left(\lambda_{2}+\right.\right. \\
& \left.\left.\gamma_{3} \operatorname{lnODI}_{i, t-1}\right) \operatorname{lnRW}_{i, t-1}+\lambda_{3} \operatorname{lnODI}_{i, t-1}\right]+\beta T_{i}+\varepsilon_{i, t}
\end{aligned}
$$

where $L$ is labour remand expressed as the number of employees in a given sector, $Y$ is the variable representing output, which is captured here as sector-level value added or output, respectively, $W$ is sectorlevel average wage, $R W$ is real wage i.e. the sector-level average nominal wage deflated by the $C P I, O D I$ is the stock of overseas direct investment at the sector level (as a percentage of domestic industry output), $T$ is the sector-specific time trend which allows for labour-augmenting technical progress and $\varepsilon$ is the error term. In denotes logarithmic form. As output produced domestically includes imported intermediate inputs, this variable, used as an alternative to value added in this paper, captures some of the effects of outsourcing. Equation (1) is specified in a way so that the long-run effects on employment can be checked.

25. Interacting the ODI variable (scaled by output) with the adjustment term allows to check whether ODI alters the speed of adjustment in domestic employment following changes in output and wages. A negative (positive) sign for the adjustment coefficient means that the adjustment of employment has become faster (slowed). Interaction of the ODI variable with the wage variable in turn reflects whether outward direct investment changes the domestic price elasticity of demand for labour in the sector in which ODI is made. A negative (positive) sign for the wage interaction term means that the labour demand curve has become more (less) elastic.

26. The data set is arranged as a panel, where $i$ indicates the sector and $t$ the year. The dataset compiles all publicly available data, i.e. 34 sectors (16 manufacturing and 18 services, agriculture, and other industries). The availability of sector-level data (from 2003) on a comparable basis restricts the length of the dataset to maximum 15 years, but depending on the industry, some variables have an even shorter time dimension. The Chinese GB/T 4754-2011 industry classification system is applied as all the domestic data are available only by that classification.

27. This paper uses the sum of the cumulated stock of greenfield and M\&A investment to interpolate the official ODI stock data as a proxy of overseas direct investment to overcome the classification issues related to the official data released by the Ministry of Commerce. Those issues are (i) investment by overseas affiliates of Chinese firms is not counted as ODI, (ii) investment through third parties is not showed as Chinese ODI in the ultimate destination economy and (iii) investment through third parties appears as investment in leasing and business services in the first destination economy, not according to the sector where the ultimate investment is made at the ultimate destination. In particular, this latter classification issue can potentially be misleading as according to the official classification, nearly a half of 
overall services investment is made in leasing and business services, while according to greenfield investment project and M\&A deal data, only about $5 \%$ (not to mention the much smaller size of services ODI in the dataset compiled from micro data). As firm-level greenfield project and M\&A deal data follow different sector classifications, they needed to be reclassified to follow the Chinese official statistics classification. The matching of greenfield investment sector classification with the Chinese national one is in Annex B (Table A B1). The M\&A deals data follow international standards and could therefore be matched with Chinese national data using sectoral correspondence tables in Annex B (Table A B2).

28. Other sector-level variables are neither readily available, and thus were constructed by exploiting all available data including all population and economic censuses to date. The details of the construction of employment, wage, value added, investment and output data are in Annex C.

29. As the dataset may be subject to endogeneity and other issues, the OLS may not be the most suitable estimator. Hence Equation (1) is estimated using the panel with corrected serial correlation and the instrumental variables estimators (Table 2). The former estimator assumes that the disturbances are heterosckedastic and contemporaneously correlated across panels. The instrumental variables estimation treats employment, output and wages as endogenous and uses their lagged terms as instruments.

\section{Table 2. ODI reduces domestic employment and the price elasticity of labour demand and} increases the speed of adjustment

Results from the pooled dataset

\begin{tabular}{|c|c|c|}
\hline Dependent variable: labour demand & Instrumental variables & Panel corrected serial correlation \\
\hline & \multicolumn{2}{|c|}{ Long-term } \\
\hline Output & $\begin{array}{l}0.713^{* * *} \\
(0.1487)\end{array}$ & $\begin{array}{c}0.173 \\
(0.2288)\end{array}$ \\
\hline Wage & $\begin{array}{l}-0.675^{\star *} \\
(0.2824)\end{array}$ & $\begin{array}{c}-0.641^{*} \\
(0.3324)\end{array}$ \\
\hline Outward direct investment & $\begin{array}{l}-0.135^{\star *} \\
(0.0658)\end{array}$ & $\begin{array}{l}-0.359^{* \star \star} \\
(0.1023)\end{array}$ \\
\hline Speed of adjustment & $\begin{array}{l}0.0131^{\star \star *} \\
(0.0033)\end{array}$ & $\begin{array}{l}0.005^{\star * *} \\
(0.0017)\end{array}$ \\
\hline Interaction ODI-wage & $\begin{array}{l}-0.690^{* * *} \\
(0.2967)\end{array}$ & $\begin{array}{l}-0.708^{* \star} \\
(0.3471)\end{array}$ \\
\hline Interaction ODI-output & $\begin{array}{l}0.710^{\star * \star} \\
(0.1394)\end{array}$ & $\begin{array}{c}0.212 \\
(0.2289)\end{array}$ \\
\hline \multirow[t]{2}{*}{ Time trend } & $\begin{array}{c}-0.033^{\star \star *} \\
(0.0119)\end{array}$ & $\begin{array}{c}-0.071^{* \star *} \\
(0.0226)\end{array}$ \\
\hline & \multicolumn{2}{|c|}{ Short-term } \\
\hline Dynamic coefficient & $\begin{array}{l}-0.405^{\star * \star} \\
(0.1094)\end{array}$ & $\begin{array}{l}-0.185^{\star * \star} \\
(0.0426)\end{array}$ \\
\hline Wage & $\begin{array}{c}0.335 \\
(0.3385)\end{array}$ & $\begin{array}{c}0.016 \\
(0.0482)\end{array}$ \\
\hline Output & $\begin{array}{c}0.332 \\
(0.1094)\end{array}$ & $\begin{array}{l}0.063^{* * *} \\
(0.0130)\end{array}$ \\
\hline Constant & $\begin{array}{c}-0.541 \\
(1.5568)\end{array}$ & $\begin{array}{l}1.601^{* * *} \\
(0.5016)\end{array}$ \\
\hline Observations & 433 & 461 \\
\hline R-squared & 0.0273 & 0.6081 \\
\hline Number of industries & 34 & 34 \\
\hline
\end{tabular}

Note: Standard errors in parentheses. ${ }^{* *} p<0.01,{ }^{* *} p<0.05,{ }^{*} p<0.1$. In the instrumental variable estimation, output, wage and employment are treated as endogenous and instrumented with their lagged terms.

Source: Authors' estimation. 
30. The dynamic coefficient is negative and highly significant in both models, validating the error correction specification. As expected in a labour demand equation, an increase in output boosts demand for labour while higher wages reduce it. The size of the coefficients is relatively large. ODI appears to have a negative impact on labour demand in both models. This may indicate that foreign and domestic labour are direct substitutes, or alternatively, that ODI boosts domestic productivity, reducing the level of employment required to achieve a given level of output in the short term, but raising output and employment in the longer term (Grossman and Rossi-Hansberg, 2006).

31. The positive coefficient on the interaction term of ODI with the employment variable indicates that ODI reduces the speed at which the labour market adjusts to shocks. The same was found for services industries in OECD countries, but the opposite for those manufacturing industries that that have strong commercial links with the non-OECD countries (Molnar et al., 2008). Furthermore, ODI increases the price elasticity of labour demand. A more elastic demand curve implies that as a result of overseas investment, national factor demands have become more sensitive to changes in factor prices. This may be because there is the possibility of outsourcing production to lower-wage direct investment destinations (supporting the substitution hypothesis between domestic and foreign employment).

32. The literature highlights the heterogeneity of effects across industries. To account for such potential heterogeneity, Equation (1) was next estimated using sector-specific coefficients and the panel corrected for serial correlation estimator (Table 3). The Wald test of the equality of the estimated coefficients across sectors is rejected for all variables, suggesting that there is indeed heterogeneity across sectors.

Table 3. ODI reduces labour demand in some labour-intensive manufacturing industries Results from the panel corrected for serial correlation with sector-specific coefficients

\begin{tabular}{|c|c|c|}
\hline \multicolumn{2}{|c|}{ Dependent variable: labour demand } & Panel-corrected standard error \\
\hline \multicolumn{3}{|l|}{ Long term } \\
\hline \multirow[t]{2}{*}{ Output } & Positive significant & BUSINESS PAPER TRADE \\
\hline & Not significant & 26 \\
\hline \multirow[t]{2}{*}{ Wage } & Negative significant & NMETAL PAPER WATER \\
\hline & Not significant & 24 \\
\hline \multirow[t]{3}{*}{ Outward direct investment } & Negative significant & $\begin{array}{c}\text { CHEM CLOTH CON ELECTRO FOOD IT METALS METALP NMETAL PAPER } \\
\text { RESEARCH TEX TRANS }\end{array}$ \\
\hline & Positive significant & BUSINESS OTHER \\
\hline & Not significant & 19 \\
\hline \multirow[t]{3}{*}{ Speed of adjustment } & Positive significant & BUSINESS METALS METALP OTHER TRADE \\
\hline & Negative significant & COM ELECTRO INS IT MACHI PAPER PETRO RESEARCH TRAFFIC \\
\hline & Not significant & 20 \\
\hline \multirow[t]{3}{*}{ Interaction ODI-wage } & Positive significant & BUSINESS COM ELECTRO HOTEL INS IT METALS OTHER PETRO RESEARCH \\
\hline & Negative significant & NMETAL PAPER \\
\hline & Not significant & 22 \\
\hline \multirow[t]{3}{*}{ Time trend } & Positive significant & ELECTRO HOTEL OTHER PETRO RESEARCH TEX TRADE WATER \\
\hline & Negative significant & IT NMETAL TRANS \\
\hline & Not significant & 23 \\
\hline \multicolumn{3}{|l|}{ Short term } \\
\hline \multirow[t]{2}{*}{ Dynamic coefficient } & Negative significant & $\begin{array}{l}\text { BUSINESS CONS FINANCE NMETAL METALS METALP MACHI OTHER TRADE } \\
\text { TRANS WATER WOOD }\end{array}$ \\
\hline & Not significant & 16 \\
\hline \multirow[t]{2}{*}{ Output } & Positive significant & $\begin{array}{c}\text { BUSINESS COM ELECTRO FOOD HOUSEHOLD INS MACHI NMETAL PAPER } \\
\text { PETRO RESEARCH }\end{array}$ \\
\hline & Not significant & 19 \\
\hline
\end{tabular}




\begin{tabular}{l|c|c}
\hline \multirow{2}{*}{ Wage } & Negative significant & BUSINESS FINANCE HOUSEHOLD METALP OTHER PAPER WATER \\
\cline { 2 - 3 } & Not significant & 19 \\
\hline Year controlled & & yes \\
\hline Observations & 461 \\
\hline R-squared & 0.9858 \\
\hline Number of industries & 34 \\
\hline
\end{tabular}

Note: Industry classification follows the GB/T 4754-2011 system. Significance is at least at the $10 \%$ level. The sector abbreviations used in the table are the following: AGR agriculture, forestry, animal husbandry and fishery, MIN mining, FOOD manufacture of food and tobacco, TEX manufacture of textile, CLOTH manufacture of textile wearing apparel, footwear, leather, fur, feather and related products and caps, WOOD processing of timber, manufacture of wood and manufacture of furniture bamboo, rattan, palm and straw products, PAPER manufacture of paper and paper products, manufacture of articles for culture, education and sport activities, PETRO processing of petroleum and coking, CHEM manufacture of chemical materials, NMETAL manufacture of non-metallic mineral products, METALS smelting and pressing of metals, METALP manufacture of metal products, MACHI manufacture of general and special purpose machinery, TRANS manufacture of transport equipment, ELECTRO manufacture of electrical machinery and equipment, COM manufacture of communication equipment, computers and other electronic equipment, INS manufacture of measuring instruments and machinery for cultural activity and office work, OTHER other manufacturing, ELECT production and distribution of electricity, gas and water, CONS construction, TRADE wholesale and retail trades, TRAFFIC traffic, transport, storage and post, HOTEL hotels and catering services, IT information transmission, computer services and software, FINANCE financial intermediation, ESTATE real estate, BUSINESS leasing and business services, RESEARCH scientific research, technical service and geologic prospecting, WATER management of water conservancy, environment, HOUSEHOLD services to households and other services, HEALTH health, social security and social welfare, EDU education, CULTURE culture, sports and entertainment, PUB public management and social organisation.

Source: Authors' estimation.

33. Among the 34 sectors, in 13 , the coefficient on ODI is negative and statistically significant. In many manufacturing industries where Chinese companies are traditionally strong such as food, textiles, clothing, metals, metal products, electronics and transport equipment, the impact of overseas direct investment on domestic employment is negative, potentially indicating relocation of production to places with lower labour costs or closer to the market. This is also the case for some services, such as construction or scientific research. In the case of business services, however, the impact is positive and statistically significant, reflecting additional need for human resources in the source country as overseas production is likely to target overseas customers and may need additional staff at home to coordinate those activities.

34. Furthermore, ODI increases the speed of adjustment in some sectors, thereby making labour more vulnerable there, while in other sectors it reduces the speed at which the labour market adjusts to shocks, therefore it appears to act as a buffer. There are more sectors where adjustment becomes faster, these include manufacturing industries such as electronics, transport equipment, instruments, machinery, paper products and petrochemicals as well as some services such as IT, transportation and scientific research. In contrast, as a result of ODI, domestic labour market adjustment becomes slower in metals and metal product manufacturing, business services and wholesale and retail trade.

35. The impact of ODI on the price elasticity of labour demand also varies by sector. It reduces price elasticity in metals, petrochemicals, electronics, telecommunications and instruments manufacturing as well as some services such as business services, accommodation, IT and scientific research, but increases in non-metallic minerals and paper products. A more elastic demand curve implies that as a result of ODI, national factor demands have become more sensitive to changes in factor prices. This, however, appears to be the case only in those two sectors. In the case of paper product manufacturing, ODI makes the labour demand curve more elastic and at the same time increases the speed of adjustment in labour markets. In contrast, there are two sectors, where ODI makes the labour demand curve less elastic and reduces the speed of adjustment in labour markets, those are metals manufacturing and business services.

36. The above estimations use gross output as the output variable in Equation (1), but using the value added would produce similar results, though with fewer coefficients being significant as the construction of the value added variable is based to a greater extent on extrapolations and is also available for fewer observations than the gross output variable. 


\section{The impact of ODI on domestic investment}

37. Intuitively, relocation of production facilities overseas reduces domestic investment, while the impact of the expansion of existent activities or venturing into new activities on domestic investment is uncertain ex ante. To check the actual impact of ODI on domestic fixed asset investment, below an accelerator-type relationship is assumed between fixed asset investment and output and is augmented by ODI. Equation (2) is estimated using the panel corrected serial correlation estimator:

$$
\Delta \operatorname{lnFAI} i_{i, t}=a_{0}+a_{1} \Delta \ln Y_{i, t}+a_{4}\left(\operatorname{lnFAI} i, t-1+\lambda_{1} \ln Y_{i, t-1}+\lambda_{2} \operatorname{lnODI}_{i, t-1}\right)+\beta T_{i}+\varepsilon_{i, t}
$$

where $F A l$ is fixed asset investment in a given sector, $Y$ is the variable representing output, which is captured here as sector-level output, $O D I$ is the stock of overseas direct investment at the sector level (as a percentage of domestic industry output), $T$ is the sector-specific time trend and $\varepsilon$ is the error term. In denotes logarithmic form.

\section{Table 4. The overall impact of ODI on fixed asset investment is not statistically significant}

Results from the panel corrected for serial correlation

\begin{tabular}{l|c}
\hline \multicolumn{1}{c}{ Dependent variable: fixed asset investment } & Panel-corrected serial correlation \\
\hline Long-term coefficients & $0.542^{* *}$ \\
\hline Output & $(0.2667)$ \\
\hline Outward direct investment & 0.013 \\
& $(0.0560)$ \\
\hline Time trend & $0.099^{* *}$ \\
& $(0.0356)$ \\
\hline Short-term coefficients & \\
\hline Dynamic coefficient & $-0.238^{* * *}$ \\
& $(0.0304)$ \\
\hline Output & 0.070 \\
& $(0.0739)$ \\
\hline Constant & 2.553 \\
& $(1.7854)$ \\
\hline Observations & 461 \\
\hline R-squared & 0.6081 \\
\hline Number of industries & 34 \\
\hline
\end{tabular}

Note: Standard errors in parentheses. ${ }^{* *} p<0.01,{ }^{* *} p<0.05,{ }^{*} p<0.1$.

Source: Authors' estimation.

38. In the overall regression with common coefficients across sectors (Table 4), the impact of ODI on domestic fixed asset investment appeared positive, but not significant, implying that overall, an increasing ODI (relative to output) may not have an impact on domestic fixed asset investment. Using common coefficients, however, may mask cross-sector heterogeneity, therefore in the next step, sector-specific coefficients were applied. Indeed, the hypothesis that the coefficients are equal across sectors is rejected by the Wald test for all variables of interest. 
Table 5. Outward direct investment tends to have a negative impact on fixed asset investment Results from the panel corrected for serial correlation with sector-specific coefficients

\begin{tabular}{|c|c|c|}
\hline \multicolumn{2}{|c|}{ Dependent variable: fixed asset investment } & Panel-corrected serial correlation \\
\hline \multicolumn{3}{|c|}{ Long term } \\
\hline \multirow[t]{2}{*}{ Output } & Positive significant & CULTURE FINANCE HOUSEHOLD IT \\
\hline & Not significant & 22 \\
\hline \multirow[t]{3}{*}{$\begin{array}{l}\text { Outward } \\
\text { investment }\end{array}$} & $\begin{array}{l}\text { Negative } \\
\text { significant }\end{array}$ & AGR CLOTH CONS CULTURE ELECTRO MIN OTHER TEX TRANS \\
\hline & Positive significant & - \\
\hline & Not significant & 25 \\
\hline \multirow[t]{3}{*}{ Time trend } & Positive significant & $\begin{array}{l}\text { AGR BUSINESS COM CONS ELECT METALP MIN OTHER PAPER PETRO RESEARCH TEX } \\
\text { TRADE TRANS WATER }\end{array}$ \\
\hline & $\begin{array}{l}\text { Negative } \\
\text { significant }\end{array}$ & IT \\
\hline & Not significant & 18 \\
\hline \multicolumn{3}{|l|}{ Short term } \\
\hline \multirow[t]{2}{*}{ Dynamic coefficient } & $\begin{array}{l}\text { Negative } \\
\text { significant }\end{array}$ & $\begin{array}{c}\text { AGR BUSINESS COM CONS CULTURE ELECT IT METALP OTHER PAPER PETRO PUB } \\
\text { RESEARCH TEX TRANS WATER }\end{array}$ \\
\hline & Not significant & 18 \\
\hline \multirow[t]{2}{*}{ Output } & Positive significant & CHEM FINANCE HOUSEHOLD INS IT NMETAL OTHER PAPER RESEARCH TRANS \\
\hline & Not significant & 24 \\
\hline \multicolumn{2}{|l|}{ Year controlled } & yes \\
\hline \multicolumn{2}{|l|}{ Observations } & 473 \\
\hline \multicolumn{2}{|l|}{ R-squared } & 0.9104 \\
\hline \multicolumn{2}{|l|}{ Number of industries } & 34 \\
\hline
\end{tabular}

Note: Industry classification follows the GB/T 4754-2011 system. Significance is at least at the $10 \%$ level. The sector abbreviations used in the table are the following: AGR agriculture, forestry, animal husbandry and fishery, MIN mining, FOOD manufacture of food and tobacco, TEX manufacture of textile, CLOTH manufacture of textile wearing apparel, footwear, leather, fur, feather and related products and caps, WOOD processing of timber, manufacture of wood and manufacture of furniture bamboo, rattan, palm and straw products, PAPER manufacture of paper and paper products, manufacture of articles for culture, education and sport activities, PETRO processing of petroleum and coking, CHEM manufacture of chemical materials, NMETAL manufacture of non-metallic mineral products, METALS smelting and pressing of metals, METALP manufacture of metal products, MACHI manufacture of general and special purpose machinery, TRANS manufacture of transport equipment, ELECTRO manufacture of electrical machinery and equipment, COM manufacture of communication equipment, computers and other electronic equipment, INS manufacture of measuring instruments and machinery for cultural activity and office work, OTHER other manufacturing, ELECT production and distribution of electricity, gas and water, CONS construction, TRADE wholesale and retail trades, TRAFFIC traffic, transport, storage and post, HOTEL hotels and catering services, IT information transmission, computer services and software, FINANCE financial intermediation, ESTATE real estate, BUSINESS leasing and business services, RESEARCH scientific research, technical service and geologic prospecting, WATER management of water conservancy, environment, HOUSEHOLD services to households and other services, HEALTH health, social security and social welfare, EDU education, CULTURE culture, sports and entertainment, PUB public management and social organisation.

Source: Authors' estimation.

39. Among the 34 sectors, in nine, the coefficient on ODI is negative and statistically significant (Table 5) suggesting substitution, i.e. increasing ODI (relative to output) is associated with lower investment at home. These sectors include manufacturing industries such as textiles, clothing, electronics and transport equipment and other manufacturing as well as agriculture, mining, construction and cultural services. In the case of those manufacturing industries, relocation of production may be behind the negative relationship between ODI and domestic investment. ODI in agriculture and mining can also potentially replace domestic investment if, for instance, it is done in lower-cost destinations. For construction and cultural services, localisation of services production that were originally exported, may provide an explanation for the negative relationship between ODI and domestic investment. 


\section{Wrapping up}

40. This paper showed that the sectoral distribution of China's outward direct investment may actually be quite different from what official data suggest. In particular, manufacturing ODI is more prominent than publicly available data show. In a very short time, China has become a major international investor, ranking among the top five in terms of ODI stock in many sectors, and for many countries, it has become a major source of FDI. Data availability, however, has not caught up with the pace of outward investment. Still no data are published on overseas affiliates' activities and even the size of outward investment is not available for manufacturing industries.

41. The analysis of the impact of China's ODI on domestic employment shows that the overall impact is negative, though there is considerable heterogeneity across sectors. This finding is in line with that in OECD countries, but not so much with the (very scarce) existing literature for China, where ODI appears to have a positive impact on domestic employment. The different results between this and those few studies can be related to different time periods and different things captured (e.g. the existence or not of ODI vs. the actual amount of ODI etc.). In many manufacturing industries where Chinese companies are traditionally strong such as food, textiles, clothing, metals, metal products, electronics and transport equipment, the impact of overseas direct investment on domestic employment is negative, potentially indicating relocation of production to places with lower labour costs or closer to the market. This is also the case for some services, such as construction or scientific research. In the case of business services, however, the impact is positive and statistically significant, reflecting additional need for human resources in the source country as overseas production is likely to target overseas customers and may need additional staff at home to coordinate those activities.

42. The analysis of the impact of China's ODI on domestic fixed asset investment reveals that in nine sectors there may be substitution, i.e. increasing ODI (relative to output) is associated with lower investment at home. In the case of manufacturing industries such as textiles, clothing, electronics and transport equipment and other manufacturing, relocation of production may be behind the negative relationship between ODI and domestic investment. ODI in agriculture and mining can also potentially replace domestic investment if, for instance, it is done in lower-cost destinations. For construction and cultural services, localisation of services production that were originally exported, may provide an explanation for the negative relationship between ODI and domestic investment.

43. Even though the impact of ODI on the domestic economy is not as clear-cut as in OECD countries (which may at least to some extent be related to the much shorter history of ODI for China), it tends to be rather negative, supporting the substitution/relocation or moving closer to market/consumers hypotheses. For future research, a more granular sector-level or even a firm-level analysis could provide further insights and answers to many questions. Using overseas affiliate data in the same context as in Molnar et al. (2008) is also an area to explore. In addition, it would also be worth testing whether the geographical dimension of ODI impacts the way ODI and domestic employment and/or investment interact. 


\section{References}

Bernard, A.B., J.B. Jensen, S.J. Redding and P.K. Scott (2018), "Global firms", Journal of Economic Literature, Vol. 56/2.

De Beule, F., D. Somers and H. Zhang (2018), "Who follows whom? A location study of Chinese private and State-owned companies in the European Union", Management International Review, Vol. 58/1.

Grossman, G. and E. Rossi-Hansberg (2006), "Trading Tasks: A Simple Theory of Offshoring", National

Bureau of Economic Research Working Paper No. 12721.

HSBC (2016), On the New Silk Road V - What Chinese companies are buying overseas?

Li, J., P. Li and B. Wang (2018), "The liability of opaqueness: State ownership and the likelihood of deal completion in international acquisitions by Chinese firms", Strategic Management, Vol. 40.

Li, L., G. Bai and G. Xian (2016), "Duiwai zhijie touzi ruhe yingxiangle muguo jiuye ? - Jiyu Zhongguo weiguan qiye shujude yanjiu", in Chinese, "How does outward foreign direct investment affect homecountry employment: Based on China's micro-level enterprises database”, Jingji Yanjiu Vol. 2016/8.

Ministry of Commerce (2020), Report on Development of China's Outward Investment and Economic Cooperation.

Ministry of Commerce (2019), 2018 Statistical Bulletin of China's Outward Foreign Direct Investment.

Ministry of Commerce (2018), 2017 Statistical Bulletin of China's Outward Foreign Direct Investment.

Ministry of Commerce, National Bureau of Statistics and State Administration of Foreign Exchange (2016), Duiwai Zhijie Touzi Tongji Zhidu, in Chinese, Statistical System of Overseas Direct Investment.

Ministry of Commerce, National Bureau of Statistics and State Administration for Foreign Exchange (2020), 2019 Statistical Bulletin of China's Outward Foreign Direct Investment.

Molnár, M., N. Pain and D. Taglioni (2008), "Globalisation and employment in the OECD", OECD Journal: Economic Studies, Vol. 2008(1), OECD Publishing, Paris. http://dx.doi.org/10.1787/eco_studies-v2008-art3-en

National Committee on US-China Relations and Rhodium Group (2017), New Neighbors: 2017 Update Chinese Investment in the United States by Congressional District.

Natixis (2018), China's Overseas Mergers and Acquisitions May Not Have Slowed down in 2017 and Will Probably Boom in 2018.

OECD (2019), Economic Survey of China, OECD Publishing, Paris.

Scissors, D. (2017), CFIUS, Chinese Investment and How to Improve Both? American Enterprise Institute.

Scissors, D. (2018), Private Data, not Private Firms: The real issues in Chinese investment, American Enterprise Institute.

Song, L., W. Xie and H. He (2017), "Duiwai zhijie touzi dui woguo jiuye yingxiangde shizheng yanjiu Jiyu menxian mianban moxing de fenxi", in Chinese, "Empirical research on the effect of OFDI on China's employment - Based on the threshold panel data model", Modern Economic Science, Vol. 2017(35-5). 


\section{Annex A. Chinese ODI by the official data}

44. According to both Chinese official data released by the Ministry of Commerce and the IMF's Coordinated Direct Investment Survey (CDIS), the major destination of Chines direct investment is Hong Kong, China. Tax havens such as the Cayman Islands, the British Virgin Islands come next followed by the United States and Singapore, then by Australia, the Netherlands, the United Kingdom, Luxembourg and Russia/Germany (Figure A.1). ODI data by MOFCOM report the immediate destination. In the case of tax havens, the ultimate destination is reported, with the exception where investment is flowing back to China. Thus, tax havens like the Cayman or the British Virgin Islands appear as destinations in this latter case. The ranking by the Co-ordinated Direct Investment Statistics (CDIS) database by the IMF looks somewhat different. Hong Kong, China still ranks first, but Singapore is now ahead of the United States, followed by the Netherlands and Australia. Canada, which does not make it to the top 10 by the MOFCOM statistics, now ranks sixth. The United Kingdom and Russia, in contrast, do not make it to the top ten by the IMF statistics. The CDIS also collects direct investment data by immediate (first) counterpart economy, though tax havens are not included as destination.

\section{Figure A.1. The United States is the major destination of Chinese ODI}

Percentage of ODI stock, 2018
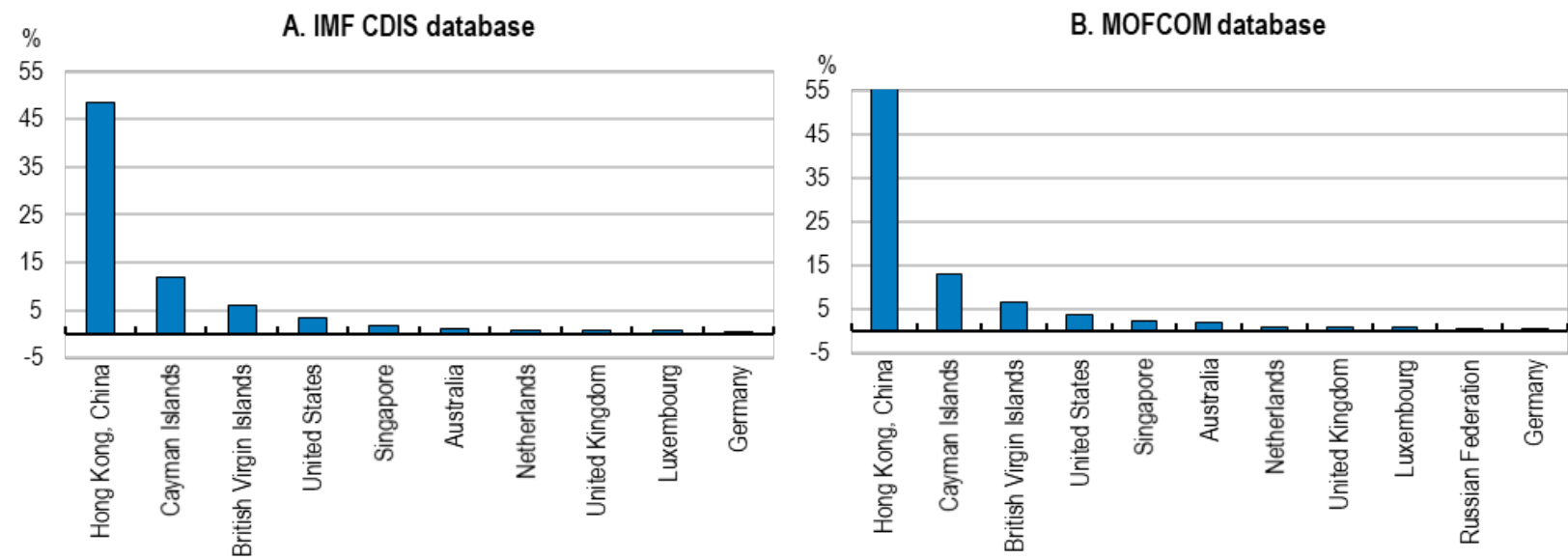

Source: CEIC and IMF Coordinated Direct Investment Statistics databases.

45. "Mirror data", i.e. bilateral data of destination countries of their inward Chinese FDI stocks could be useful for benchmarking. Official US data by the Bureau of Economic Analysis shows that US inward FDI by China is more or less in line with Chinese official ODI to the United States (Figure A.3). Exceptions are 2012-15 and 2017-18. In particular, in 2018, ODI by Chinese official data is roughly USD 155 billion higher than FDI by US official data. At the sectoral level, there are greater discrepancies (which may be related to the differing classification systems) (Figure A.3). Where the US official data show greater values such as in manufacturing and real estate, it is likely that part of the investment not reflected in Chinese official data are through third-party investment vehicles. 
Figure A.2. In recent years, Chinese ODI to the United States by the official data are higher than US official data suggest

ODI stocks

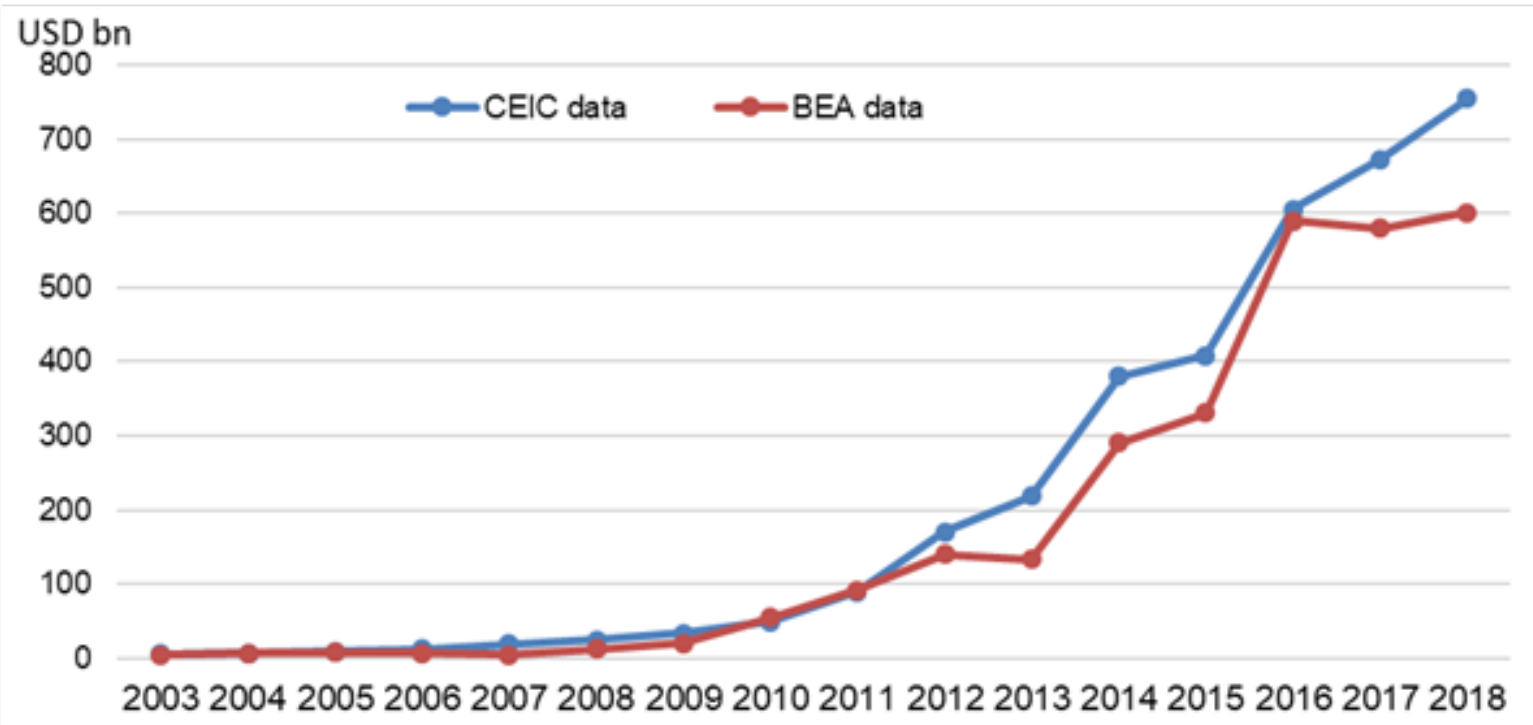

Source: CEIC and Bureau of Economic Analysis databases.

Figure A.3. In finance, IT and wholesale and retail trade there are large discrepancies in China's ODI to the United States and US FDI from China

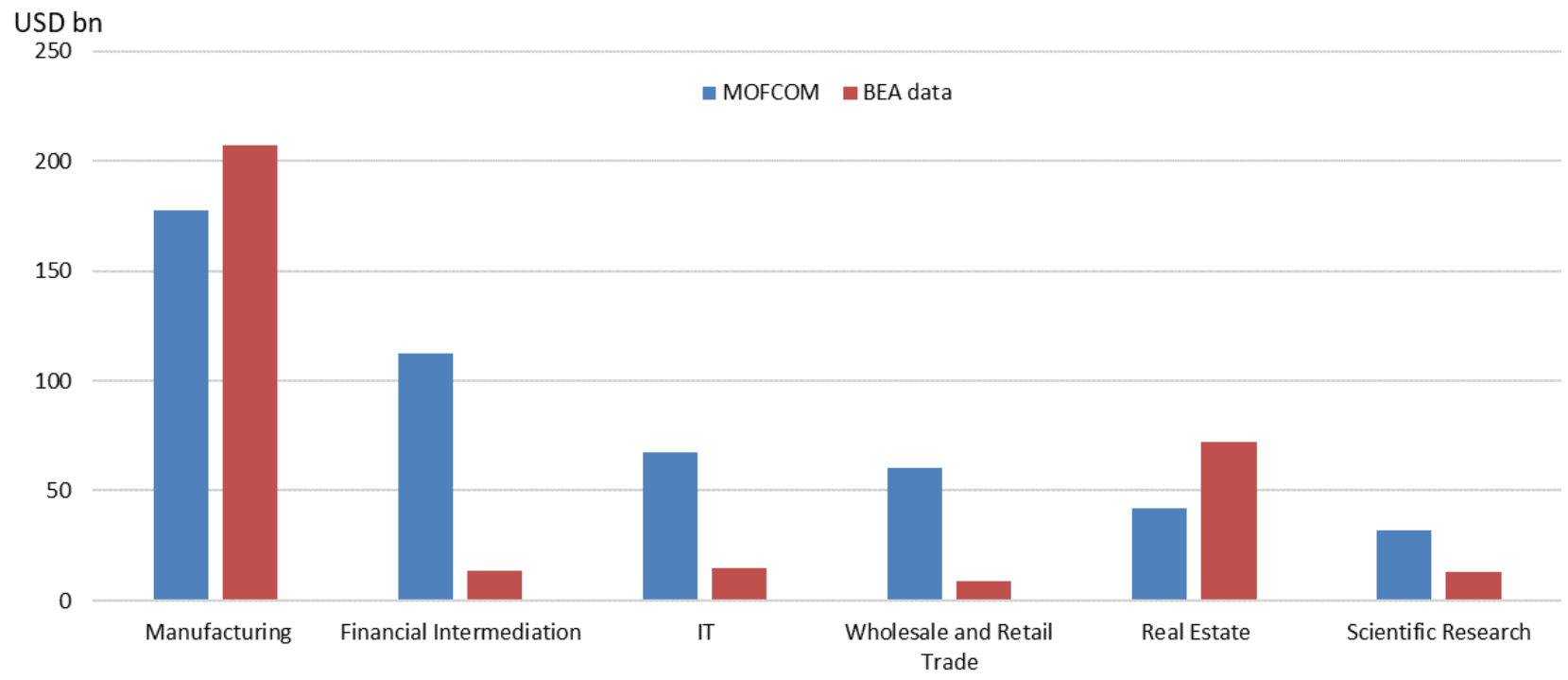

Note: Only sectors for which the Bureau of Economic Analysis reports data are shown in the chart.

Source: CEIC and Bureau of Economic Analysis databases.

46. The sectoral classification of MOFCOM data indicates that roughly $77 \%$ of Chinese ODI went to the tertiary industry as of 2018 (Figure A.4). Leasing and business services attracted most Chinese ODI, comprising nearly $44 \%$ of all tertiary industry ODI. This relates to the practice to record investment through 
third party vehicles as leasing and business investment and not according to the sector where the investment is actually destined. This way, Hong Kong, China and tax haven economies receive a lot of leasing and business services investment from China.

\section{Figure A.4. Most Chinese ODI goes to services, in particular leasing and business services}

MOFCOM data

\section{A. ODI has been concentrated in services}

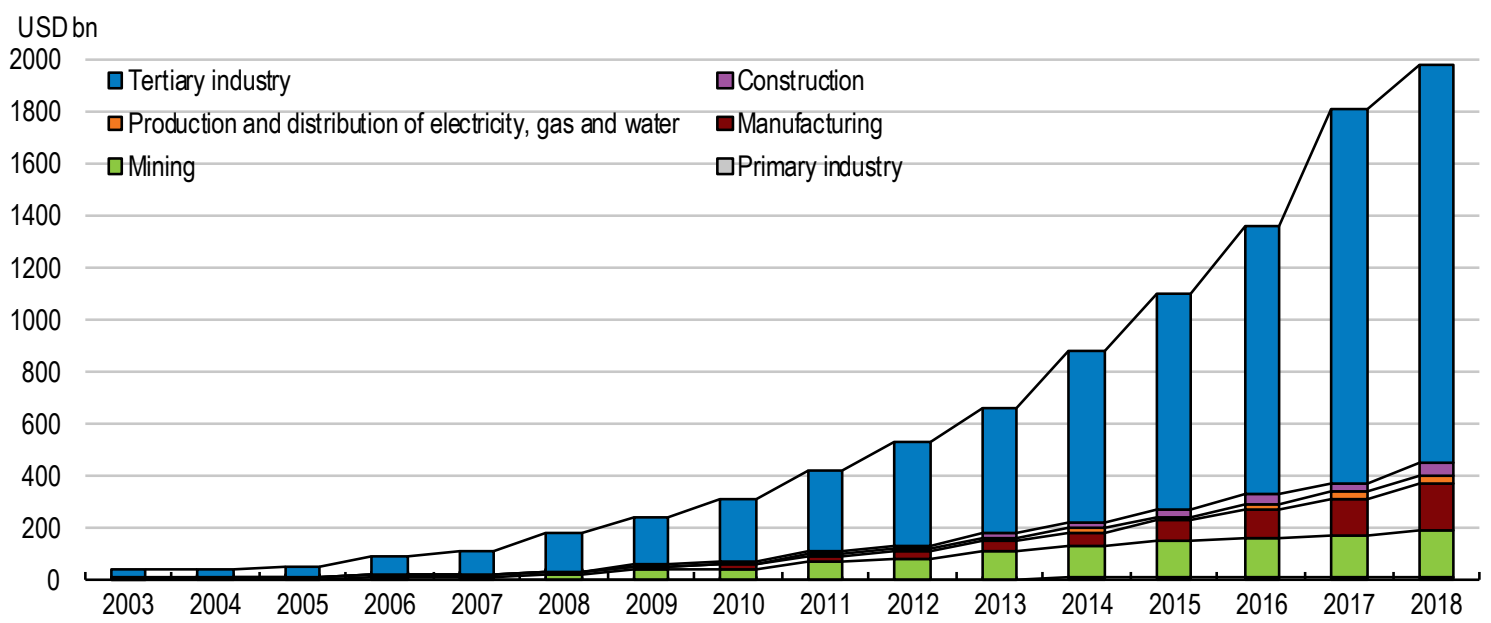

B. ODI in leasing and business services makes up nearly half of the services total, 2018

Leasing and business services
Financial intemediation
Wholesale and retail trades
Information transmission, computer
services and software
Real Estate
Traffic, transport, storage and post
Scientific research, technical
service and geologic prospecting
Services to households and other
services
Other services

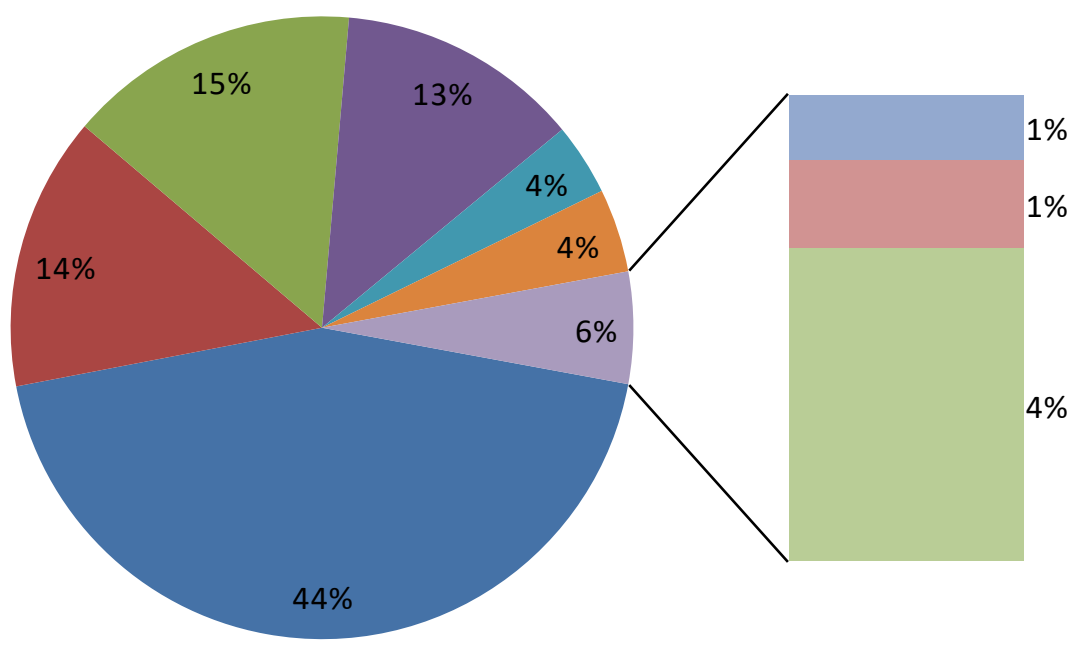

Note: The tertiary industry does not include construction in the Chinese classification. Source: CEIC database.

47. By the official classification, China's manufacturing ODI appears very small, at slightly above $9 \%$ of the total ODI stock as of 2018. It has, however, expanded rapidly: nearly doubled in two years and nearly quadrupled in five (Figure A.5). But it remains less than a sixth of that of the United States and a fifth of Japan's, and it is comparable to Korea's. However, using the newly constructed data, as discussed in this paper, China's manufacturing ODI stock is comparable to Japan's (Figure A.6). 
Figure A.5. China's manufacturing ODI stock grew rapidly

\section{MOFCOM data}

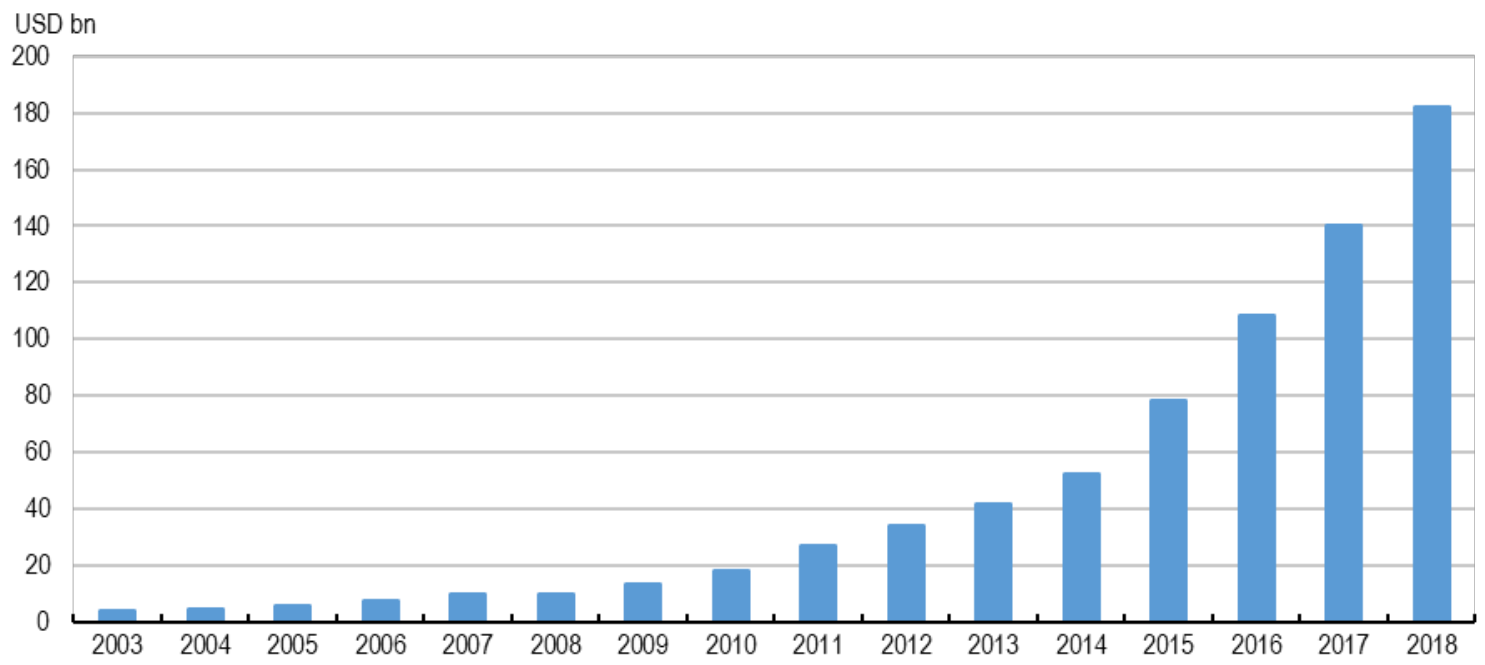

Source: CEIC database.

Figure A.6. The manufacturing ODI stock is of similar size of Korea's by MOFCOM data and of Japan's from greenfield projects and M\&A deals data

2016

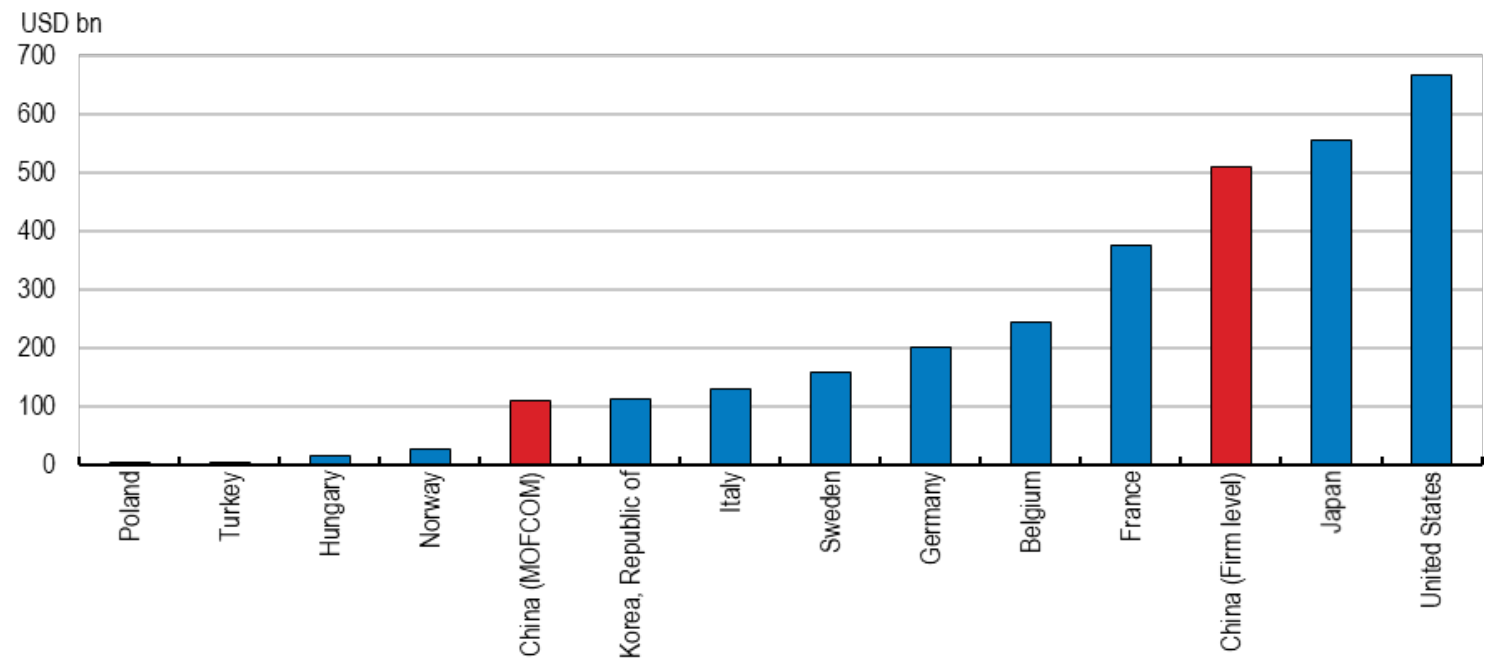

Note: In the China (Firm level) bar, outward direct investment stocks are calculated by cumulating deal values of mergers and acquisitions and of greenfield investment values over time. Data series start in 1997 for mergers and acquisitions and 2003 for greenfield investment projects.

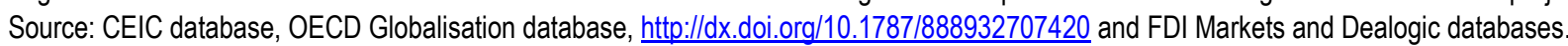

48. While either the sectoral or the geographical distribution of China's ODI can be traced from official data (with all the caveats related to the compilation), there are limited publicly available data that combine those two dimensions. MOFCOM only discloses sector-specific ODI data for the six economies of Hong Kong, China; the European Union, the United States, the ASEAN, Australia and Russia. Official data indicate that in some sectors such as real estate or transportation, these six economies indeed comprise 
most ODI in those sectors (Figure A.7). At the other extreme, the overwhelming majority of IT investment goes to other destinations than those six economies. While from official data there is no way to figure out what those destinations may be, from M\&A deals it appears that Singapore, India, South Korea, the United Arab Emirates, the ASEAN, Norway, Pakistan, Japan and other BRIICS are also important destinations. In between the two extremes are finance, manufacturing and mining with $60-70 \%$ invested in the six economic areas. Hong Kong, China leads in most sectors, in finance with a share of over $50 \%$. It also commands the largest share in real estate and transport. These high shares reflect the importance of the city as a transit port for Chinese overseas investment. The European Union and the United States are favoured destinations for manufacturers with a sixth and a tenth, respectively of overall Chinese overseas manufacturing investment. In mining, Australia is a key destination commanding a ninth of Chinese overseas mining investment.

Figure A.7. Official data indicate that most ODI in finance, transport and real estate goes to Hong Kong, China

2018

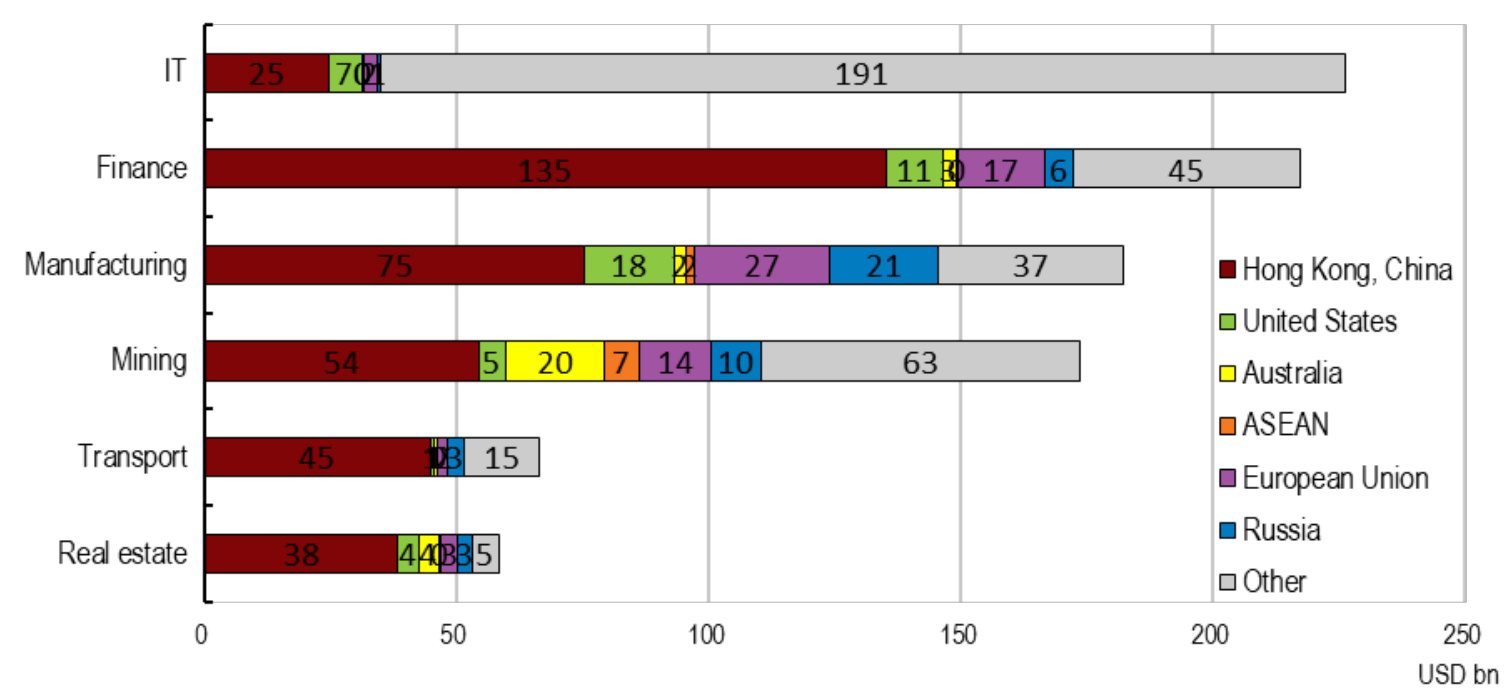

Source: Ministry of Commerce. 


\section{Annex B. Industry concordance for the M\&A and greenfield databases}

\section{Table A B.1. Concordance of Chinese sector classification and SIC}

\begin{tabular}{|c|c|}
\hline NBS & M\&A_SIC \\
\hline $\begin{array}{l}\text { Agriculture, Forestry, Animal Husbandry and } \\
\text { Fishery }\end{array}$ & $\begin{array}{l}2411 \text { - Logging } \\
0831 \text { - Forest products } \\
0912 \text { - Finfish } \\
5149 \text { - Groceries and related products, NEC } \\
0711 \text { - Soil preparation services } \\
0116 \text { - Soybeans } \\
0115 \text { - Corn } \\
0219 \text { - General livestock } \\
5261 \text { - Retail nurseries and garden stores } \\
5148 \text { - Fresh fruits and vegetables } \\
5146 \text { - Fish and seafood } \\
0131 \text { - Cotton } \\
0781 \text { - Landscape counseling and planning } \\
0213 \text { - Hogs } \\
0273 \text { - Animal aquaculture } \\
5147 \text { - Meats and meat products } \\
0211 \text { - Beef cattle feedlots } \\
0241 \text { - Dairy farms } \\
0251 \text { - Broiler, fryer, and roaster chickens } \\
5143 \text { - Dairy products, exc. dried or canned } \\
0179 \text { - Fruits and tree nuts, NEC }\end{array}$ \\
\hline Mining & $\begin{array}{l}1041 \text { - Gold ores } \\
1311 \text { - Crude petroleum and natural gas } \\
1021 \text { - Copper ores } \\
1222 \text { - Bituminous coal--underground } \\
1099 \text { - Metal ores, NEC } \\
1382 \text { - Oil and gas exploration services } \\
1221 \text { - Bituminous coal and lignite--surface } \\
5052 \text { - Coal and other minerals and ores } \\
1061 \text { - Ferroalloy ores, except vanadium } \\
1011 \text { - Iron ores } \\
1481 \text { - Nonmetallic minerals services } \\
1031 \text { - Lead and zinc ores } \\
1474 \text { - Potash, soda, and borate minerals } \\
1094 \text { - Uranium-radium-vanadium ores } \\
1241 \text { - Coal mining services } \\
1081 \text { - Metal mining services } \\
1499 \text { - Miscellaneous nonmetallic minerals } \\
1479 \text { - Chemical and fertilizer mining, NEC } \\
1389 \text { - Oil and gas field services, NEC } \\
1411 \text { - Dimension stone } \\
1231 \text { - Anthracite mining } \\
1381 \text { - Drilling oil and gas wells }\end{array}$ \\
\hline Manufacture of Food and Tobacco & $\begin{array}{l}2111 \text { - Cigarettes } \\
2021 \text { - Creamery butter }\end{array}$ \\
\hline
\end{tabular}


Manufacture of Textile

Manufacture of Textile Wearing Apparel, Footwear, Leather, Fur, Feather and Related Products and Caps

Processing of Timber, Manufacture of Wood and Manufacture of Furniture Bamboo, Rattan, Palm and Straw Products

Manufacture of Paper and Paper Products, Manufacture of Articles For Culture, Education and Sport Activities
2099 - Food preparations, NEC

2082 - Malt beverages

2048 - Prepared feeds

2033 - Canned fruits and vegetables

2096 - Potato chips and similar snacks

2084 - Wines, brandy, and brandy spirits

2076 - Vegetable oil mills

2079 - Edible fats and oils, NEC

2052 - Cookies and crackers

2023 - Dry, condensed, evaporated products

5142 - Packaged frozen foods

2026 - Fluid milk

2063 - Beet sugar

5182 - Wine and distilled beverages

2011 - Meat packing plants

2015 - Poultry slaughtering and processing

2032 - Canned specialties

2087 - Flavoring extracts and syrups, NEC

2092 - Fresh or frozen prepared fish

2281 - Yarn spinning mills

2269 - Finishing plants, NEC

2299 - Textile goods, NEC

2297 - Nonwoven fabrics

2231 - Broad woven fabric mills, wool

2261 - Finishing plants, cotton

2254 - Knit underwear mills

2211 - Broad woven fabric mills, cotton

2399 - Fabricated textile products, NEC

2329 - Men's \& boys' clothing, NEC

3144 - Women's footwear, except athletic

2389 - Apparel and accessories, NEC

2311 - Men's \& boys' suits \& coats

3199 - Leather goods, NEC

2339 - Women's \& misses' outerwear, NEC

2371 - Fur goods

2337 - Women's \& misses' suits and coats

5136 - Men's and boys' clothing

3149 - Footwear, except rubber, NEC

5137 - Women's and children's clothing

2331 - Women's \& misses' blouses \& shirts

5023 - Home furnishings

2435 - Hardwood veneer and plywood

2499 - Wood products, NEC

2511 - Wood household furniture

2519 - Household furniture, NEC

2429 - Special product sawmills, NEC

2452 - Prefabricated wood buildings

2591 - Drapery hardware, blinds and shades

2515 - Mattresses and bedsprings

2621 - Paper mills

2671 - Paper coated \& laminated, packaging

5169 - Chemicals \& allied products, NEC

2676 - Sanitary paper products

5094 - Jewelry \& precious stones

5099 - Durable goods, NEC

2679 - Converted paper products, NEC

2673 - Bags: plastics, laminated, \& coated

2759 - Commercial printing, NEC

5091 - Sporting \& recreational goods

2678 - Stationery products 


\begin{tabular}{|c|c|}
\hline & $\begin{array}{l}2657 \text { - Folding paperboard boxes } \\
5162 \text { - Plastics materials \& basic shapes }\end{array}$ \\
\hline Processing of Petroleum and Coking & $\begin{array}{l}2911 \text { - Petroleum refining } \\
2999 \text { - Petroleum and coal products, NEC } \\
2951 \text { - Asphalt paving mixtures and blocks }\end{array}$ \\
\hline Manufacture of Chemical Materials & $\begin{array}{l}2841 \text { - Soap and other detergents } \\
2892 \text { - Explosives } \\
2869 \text { - Industrial organic chemicals, NEC } \\
2899 \text { - Chemical preparations, NEC } \\
2879 \text { - Agricultural chemicals, NEC } \\
2836 \text { - Biological products exc. diagnostic } \\
2819 \text { - Industrial inorganic chemicals, NEC } \\
2835 \text { - Diagnostic substances } \\
2833 \text { - Medicinals and botanicals } \\
3021 \text { - Rubber and plastics footwear } \\
3086 \text { - Plastics foam products } \\
3081 \text { - Unsupported plastics film \& sheet } \\
2824 \text { - Organic fibers, non-cellulosic } \\
2823 \text { - Cellulosic manmade fibers } \\
3011 \text { - Tires and inner tubes } \\
2874 \text { - Phosphate fertilizers } \\
3069 \text { - Fabricated rubber products, NEC } \\
2891 \text { - Adhesives and sealants } \\
2875 \text { - Fertilizers, mixing only } \\
2893 \text { - Printing ink } \\
3084 \text { - Plastics pipe } \\
5122 \text { - Drugs, proprietaries, and sundries } \\
2821 \text { - Plastics materials and resins } \\
2844 \text { - Toilet preparations } \\
3088 \text { - Plastics plumbing fixtures } \\
2851 \text { - Paints and allied products } \\
3053 \text { - Gaskets, packing \& sealing devices } \\
3085 \text { - Plastics bottles } \\
3052 \text { - Rubber \& plastics hose \& belting } \\
2873 \text { - Nitrogenous fertilizers } \\
2812 \text { - Alkalis and chlorine } \\
2865 \text { - Cyclic crudes and intermediates } \\
3083 \text { - Laminated plastics plate \& sheet } \\
2842 \text { - Polishes and sanitation goods } \\
2816 \text { - Inorganic pigments }\end{array}$ \\
\hline Manufacture of Non-metallic Mineral Products & $\begin{array}{l}3275 \text { - Gypsum products } \\
3231 \text { - Products of purchased glass } \\
3089 \text { - Plastics products, NEC } \\
2822 \text { - Synthetic rubber } \\
3211 \text { - Flat glass } \\
3241 \text { - Cement, hydraulic } \\
5039 \text { - Construction materials, NEC } \\
3229 \text { - Pressed and blown glass, NEC } \\
3253 \text { - Ceramic wall and floor tile } \\
3291 \text { - Abrasive products } \\
3261 \text { - Vitreous plumbing fixtures } \\
3271 \text { - Concrete block and brick }\end{array}$ \\
\hline Smelting and Pressing of Metals & $\begin{array}{l}3339 \text { - Primary nonferrous metals } \\
3365 \text { - Aluminum foundries } \\
3312 \text { - Blast furnaces and steel mills } \\
3331 \text { - Primary copper } \\
3313 \text { - Electrometallurgical products } \\
3341 \text { - Secondary nonferrous metals } \\
3334 \text { - Primary aluminum } \\
3399 \text { - Primary metal products, NEC }\end{array}$ \\
\hline
\end{tabular}


Manufacture of Metal Products

Manufacture of General and Special Purpose Machinery
3357 - Nonferrous wiredrawing \& insulating

3355 - Aluminum rolling \& drawing, NEC

3356 - Nonferrous rolling \& drawing

3353 - Aluminum sheet, plate, and foil

3317 - Steel pipe and tubes

3316 - Cold finishing of steel shapes

3364 - Nonferrous die-casting exc. aluminum

3366 - Copper foundries

3354 - Aluminum extruded products

3351 - Copper rolling \& drawing

3315 - Steel wire and related products

3411 - Metal cans

5051 - Metals service centers and offices

3433 - Heating equipment, except electric

3462 - Iron and steel forgings

3499 - Fabricated metal products, NEC

3412 - Metal barrels, drums, and pails

3441 - Fabricated structural metal

3425 - Saw blades and handsaws

3449 - Miscellaneous metal work

3443 - Fabricated plate work (boiler shops)

3511 - Turbines and turbine generator sets

3599 - Industrial machinery, NEC

3523 - Farm machinery and equipment

5083 - Farm and garden machinery

3545 - Machine tool accessories

3493 - Steel springs, except wire

3568 - Power transmission equipment, NEC

3541 - Machine tools, metal cutting types

3569 - General industrial machinery, NEC

3559 - Special industry machinery, NEC

3531 - Construction machinery

5047 - Medical and hospital equipment

3563 - Air and gas compressors

3552 - Textile machinery

5084 - Industrial machinery and equipment

3519 - Internal combustion engines, NEC

3564 - Blowers and fans

5088 - Transportation equipment \& supplies

3524 - Lawn and garden equipment

3492 - Fluid power valves \& hose fittings

3533 - Oil and gas field machinery

3585 - Refrigeration and heating equipment

3549 - Metalworking machinery, NEC

3491 - Industrial valves

3561 - Pumps and pumping equipment

3592 - Carburetors, pistons, rings, valves

3546 - Power-driven hand tools

3465 - Automotive stampings

3496 - Misc. fabricated wire products

3562 - Ball and roller bearings

3495 - Wire springs

5082 - Construction and mining machinery

3565 - Packaging machinery

3534 - Elevators and moving stairways

3535 - Conveyors and conveying equipment

3542 - Machine tools, metal forming types

3711 - Motor vehicles and car bodies

5012 - Automobiles and other motor vehicles

3714 - Motor vehicle parts and accessories 


\begin{tabular}{|c|c|}
\hline & $\begin{array}{l}3721 \text { - Aircraft } \\
3743 \text { - Railroad equipment } \\
5013 \text { - Motor vehicle supplies and new parts } \\
3731 \text { - Ship building and repairing } \\
3728 \text { - Aircraft parts and equipment, NEC } \\
3724 \text { - Aircraft engines and engine parts } \\
3751 \text { - Motorcycles, bicycles, and parts } \\
3799 \text { - Transportation equipment, NEC }\end{array}$ \\
\hline $\begin{array}{l}\text { Manufacture of Electrical Machinery and } \\
\text { Equipment }\end{array}$ & $\begin{array}{l}3639 \text { - Household appliances, NEC } \\
3629 \text { - Electrical industrial apparatus, NEC } \\
3634 \text { - Electric housewares and fans } \\
3612 \text { - Transformers, except electronic } \\
3632 \text { - Household refrigerators and freezers } \\
5065 \text { - Electronic parts and equipment, NEC } \\
3691 \text { - Storage batteries } \\
3621 \text { - Motors and generators } \\
3699 \text { - Electrical equipment \& supplies, NEC } \\
3692 \text { - Primary batteries, dry and wet } \\
3613 \text { - Switchgear and switchboard apparatus } \\
5064 \text { - Electrical appliances, TV \& radios } \\
3625 \text { - Relays and industrial controls } \\
5063 \text { - Electrical apparatus and equipment } \\
3694 \text { - Engine electrical equipment } \\
3647 \text { - Vehicular lighting equipment } \\
3648 \text { - Lighting equipment, NEC } \\
3641 \text { - Electric lamps }\end{array}$ \\
\hline $\begin{array}{l}\text { Manufacture of Communication Equipment, } \\
\text { Computers and Other Electronic Equipment }\end{array}$ & $\begin{array}{l}3672 \text { - Printed circuit boards } \\
3579 \text { - Office machines, NEC } \\
3661 \text { - Telephone and telegraph apparatus } \\
3669 \text { - Communications equipment, NEC } \\
3651 \text { - Household audio and video equipment } \\
3679 \text { - Electronic components, NEC } \\
3674 \text { - Semiconductors and related devices } \\
3663 \text { - Radio \& TV communications equipment } \\
3571 \text { - Electronic computers } \\
3577 \text { - Computer peripheral equipment, NEC } \\
3576 \text { - Computer Communications Equipment } \\
5045 \text { - Computers, peripherals \& software } \\
3677 \text { - Electronic coils and transformers } \\
3675 \text { - Electronic capacitors } \\
3678 \text { - Electronic connectors, NEC } \\
3578 \text { - Calculating and accounting equipment }\end{array}$ \\
\hline $\begin{array}{l}\text { Manufacture of Measuring Instruments and } \\
\text { Machinery for Cultural Activity and Office Work }\end{array}$ & $\begin{array}{l}3824 \text { - Fluid meters and counting devices } \\
3841 \text { - Surgical and medical instruments } \\
3829 \text { - Measuring \& controlling devices, NEC } \\
3845 \text { - Electro medical equipment } \\
3861 \text { - Photographic equipment and supplies } \\
3873 \text { - Watches, clocks, watchcases \& parts } \\
3826 \text { - Analytical instruments } \\
3821 \text { - Laboratory apparatus and furniture } \\
3822 \text { - Environmental controls } \\
3812 \text { - Search and navigation equipment } \\
3825 \text { - Instruments to measure electricity } \\
3842 \text { - Surgical appliances and supplies }\end{array}$ \\
\hline Other Manufacturing & $\begin{array}{l}3944 \text { - Games, toys, and children's vehicles } \\
3949 \text { - Sporting and athletic goods, NEC } \\
3999 \text { - Manufacturing industries, NEC } \\
5093 \text { - Scrap and waste materials } \\
3965 \text { - Fasteners, buttons, needles, \& pins } \\
3911 \text { - Jewelry, precious metal }\end{array}$ \\
\hline
\end{tabular}




\begin{tabular}{|c|c|}
\hline & $\begin{array}{l}5199 \text { - Nondurable goods, NEC } \\
3931 \text { - Musical instruments }\end{array}$ \\
\hline $\begin{array}{l}\text { Production and Distribution of Electricity, Gas and } \\
\text { Water }\end{array}$ & $\begin{array}{l}4911 \text { - Electric services } \\
5172 \text { - Petroleum products } \\
4924 \text { - Natural gas distribution } \\
4932 \text { - Gas and other services combined } \\
5171 \text { - Petroleum bulk stations \& terminals } \\
4925 \text { - Gas production and/or distribution } \\
4939 \text { - Combination utilities, NEC } \\
4923 \text { - Gas transmission and distribution } \\
4931 \text { - Electric and other services combined } \\
4941 \text { - Water supply } \\
4922 \text { - Natural gas transmission }\end{array}$ \\
\hline Construction & $\begin{array}{l}1522 \text { - Residential construction } \\
1629 \text { - Heavy construction, NEC } \\
1793 \text { - Glass and glazing work } \\
1611 \text { - Highway and street construction } \\
1791 \text { - Structural steel erection } \\
1622 \text { - Bridge, tunnel, \& elevated highway } \\
1541 \text { - Industrial buildings and warehouses } \\
1623 \text { - Water, sewer, and utility lines } \\
1542 \text { - Nonresidential construction } \\
1731 \text { - Electrical work } \\
1531 \text { - Operative builders }\end{array}$ \\
\hline Wholesale and Retail Trades & $\begin{array}{l}5942 \text { - Book stores } \\
5411 \text { - Grocery stores } \\
5722 \text { - Household appliance stores } \\
5912 \text { - Drug stores and proprietary stores } \\
5999 \text { - Miscellaneous retail stores, NEC } \\
5311 \text { - Department stores } \\
5714 \text { - Drapery and upholstery stores } \\
5812 \text { - Eating places } \\
5736 \text { - Musical instrument stores } \\
5632 \text { - Women's accessory \& specialty stores } \\
5611 \text { - Men's \& boys' clothing stores } \\
5511 \text { - New and used car dealers } \\
5941 \text { - Sporting goods and bicycle shops } \\
5621 \text { - Women's clothing stores } \\
5734 \text { - Computer and software stores } \\
5541 \text { - Gasoline service stations } \\
5961 \text { - Catalog and mail-order houses } \\
5131 \text { - Piece goods \& notions }\end{array}$ \\
\hline Traffic, Transport, Storage and Post & $\begin{array}{l}4491 \text { - Marine cargo handling } \\
4412 \text { - Deep sea foreign trans. of freight } \\
4731 \text { - Freight transportation arrangement } \\
4499 \text { - Water transportation services, NEC } \\
4512 \text { - Air transportation, scheduled } \\
4214 \text { - Local trucking with storage } \\
4131 \text { - Intercity \& rural bus transportation } \\
4785 \text { - Inspection \& fixed facilities } \\
4581 \text { - Airports, flying fields, \& services } \\
4213 \text { - Trucking, except local } \\
4513 \text { - Air courier services } \\
4789 \text { - Transportation services, NEC } \\
4212 \text { - Local trucking, without storage } \\
4111 \text { - Local and suburban transit } \\
4121 \text { - Taxicabs } \\
4424 \text { - Deep sea domestic trans. of freight } \\
4225 \text { - General warehousing and storage }\end{array}$ \\
\hline Hotels and Catering Services & 7011 - Hotels and motels \\
\hline
\end{tabular}




\begin{tabular}{|c|c|}
\hline $\begin{array}{l}\text { Information Transmission, Computer Services } \\
\text { and Software }\end{array}$ & $\begin{array}{l}7379 \text { - Computer related services, NEC } \\
4812 \text { - Radiotelephone communications } \\
4813 \text { - Telephone communications, exc. radio } \\
7372 \text { - Prepackaged software } \\
7373 \text { - Computer integrated systems design } \\
7375 \text { - Information retrieval services } \\
4899 \text { - Communication services, NEC } \\
7371 \text { - Computer programming services } \\
4833 \text { - Television broadcasting stations } \\
7374 \text { - Data processing and preparation } \\
7378 \text { - Computer maintenance \& repair }\end{array}$ \\
\hline Financial Intermediation & $\begin{array}{l}6099 \text { - Functions related to deposit banking, NEC } \\
6221 \text { - Commodity contracts brokers, dealers } \\
6719 \text { - Holding companies, NEC } \\
6799 \text { - Investors, NEC } \\
6011 \text { - Federal reserve banks } \\
6029 \text { - Commercial banks, NEC } \\
6159 \text { - Misc. business credit institutions } \\
6726 \text { - Investment offices } \\
6091 \text { - Non-deposit trust facilities } \\
6311 \text { - Life insurance } \\
6798 \text { - Real estate investment trusts } \\
6331 \text { - Fire, marine, and casualty insurance } \\
6733 \text { - Trusts } \\
6399 \text { - Insurance carriers, NEC } \\
6289 \text { - Security \& commodity services, NEC } \\
6211 \text { - Security brokers and dealers } \\
6111 \text { - Federal \& fed.-sponsored credit } \\
6722 \text { - Management investment, open-end } \\
6282 \text { - Investment advice } \\
6199 \text { - Finance Services } \\
6792 \text { - Oil royalty traders } \\
6231 \text { - Security and commodity exchanges }\end{array}$ \\
\hline Real Estate & $\begin{array}{l}6531 \text { - Real estate agents and managers } \\
6552 \text { - Sub dividers and developers } \\
6512 \text { - Nonresidential building operators }\end{array}$ \\
\hline Leasing and Business Services & $\begin{array}{l}7349 \text { - Building maintenance services, NEC } \\
7311 \text { - Advertising agencies } \\
8721 \text { - Accounting, auditing, \& bookkeeping } \\
8748 \text { - Business consulting, NEC } \\
4724 \text { - Travel agencies } \\
8111 \text { - Legal services } \\
7359 \text { - Equipment rental \& leasing, NEC } \\
8999 \text { - Services, NEC } \\
7319 \text { - Advertising, NEC } \\
8741 \text { - Management services } \\
7342 \text { - Disinfecting \& pest control services } \\
7323 \text { - Credit reporting services } \\
8742 \text { - Management consulting services } \\
7312 \text { - Outdoor advertising services }\end{array}$ \\
\hline $\begin{array}{l}\text { Scientific research, technical service and } \\
\text { geologic prospecting }\end{array}$ & $\begin{array}{l}8711 \text { - Engineering services } \\
8732 \text { - Commercial nonphysical research } \\
8731 \text { - Commercial physical research } \\
8712 \text { - Architectural services } \\
8713 \text { - Surveying services } \\
8734 \text { - Testing laboratories }\end{array}$ \\
\hline $\begin{array}{l}\text { Management of Water Conservancy, } \\
\text { Environment }\end{array}$ & $\begin{array}{l}7382 \text { - Security systems services } \\
4953 \text { - Refuse systems } \\
4952 \text { - Sewerage systems }\end{array}$ \\
\hline Services to Households and Other Services & 7383 - News syndicates \\
\hline
\end{tabular}




\begin{tabular}{|c|c|}
\hline & $\begin{array}{l}7389 \text { - Business services, NEC } \\
7261 \text { - Funeral service and crematories } \\
7299 \text { - Miscellaneous personal services, NEC } \\
7536 \text { - Automotive glass replacement shops } \\
7216 \text { - Dry-cleaning plants, except rug }\end{array}$ \\
\hline Education & $\begin{array}{l}8299 \text { - Schools \& educational services, NEC } \\
8221 \text { - Colleges and universities } \\
8211 \text { - Elementary and secondary schools }\end{array}$ \\
\hline Health, Social Security and Social Welfare & $\begin{array}{l}2834 \text { - Pharmaceutical preparations } \\
8062 \text { - General medical \& surgical hospitals } \\
4959 \text { - Sanitary services, NEC } \\
8099 \text { - Health and allied services, NEC } \\
8069 \text { - Specialty hospitals exc. psychiatric } \\
8071 \text { - Medical laboratories }\end{array}$ \\
\hline Culture, Sports and Entertainment & $\begin{array}{l}2741 \text { - Miscellaneous publishing } \\
4841 \text { - Cable and other pay TV services } \\
7999 \text { - Amusement and recreation, NEC } \\
7812 \text { - Motion picture \& video production } \\
7922 \text { - Theatrical producers and services } \\
7822 \text { - Motion picture and tape distribution } \\
2721 \text { - Periodicals } \\
2711 \text { - Newspapers } \\
2731 \text { - Book publishing } \\
7941 \text { - Sports clubs, managers, \& promoters } \\
7948 \text { - Racing, including track operation } \\
7832 \text { - Motion picture theaters, ex drive-in } \\
7819 \text { - Services allied to motion pictures }\end{array}$ \\
\hline Public Management and Social Organization & $\begin{array}{l}9111 \text { - Executive offices } \\
9199 \text { - General government, NEC } \\
9511 \text { - Air, water, \& solid waste management } \\
9512 \text { - Land, mineral, wildlife conservation }\end{array}$ \\
\hline
\end{tabular}

Note: Industry classification follows the Chinese GB/T 4754-2011 system. The M\&A deal database by Dealogic is using the SIC classification. Source: Authors' compilation.

\section{Table A B.2. Concordance of Chinese national classification and the FDI Markets database's sector classification}

\begin{tabular}{l|l}
\hline National Bureau of Statistics & Greenfield Subsectors \\
\hline Agriculture, forestry, animal husbandry and & Animal production \\
fishery & Animal slaughtering \& processing \\
& Crop production \\
& Fishing, hunting \& trapping \\
& Forestry \& logging \\
& Fruits \& vegetables \& specialist foods \\
& Grains \& oilseed \\
\hline Mining & Coal mining \\
& Copper, nickel, lead, \& zinc mining \\
& Gold ore \& silver ore mining \\
& Iron ore mining \\
& Nonmetallic mineral mining \& quarrying \\
& Oil \& gas extraction \\
& Other metal ore mining \\
& Support activities for mining \\
& Support activities for mining \& energy \\
& All other food \\
& Animal food \\
& Bakeries \& tortillas \\
\hline Manufacture of food and tobacco & Breweries \& distilleries \\
\hline
\end{tabular}




\begin{tabular}{|c|c|}
\hline & $\begin{array}{l}\text { Coffee \& tea } \\
\text { Dairy products } \\
\text { Other (Beverages) } \\
\text { Seafood products } \\
\text { Seasoning \& dressing } \\
\text { Snack food } \\
\text { Soft drinks \& ice } \\
\text { Sugar \& confectionary products } \\
\text { Tobacco } \\
\text { Wineries }\end{array}$ \\
\hline Manufacture of textile & $\begin{array}{l}\text { Apparel knitting } \\
\text { Artificial \& synthetic fibres } \\
\text { Other (textiles) } \\
\text { Textiles \& textile mills }\end{array}$ \\
\hline $\begin{array}{l}\text { Manufacture of textile wearing apparel, footwear, } \\
\text { leather, fur, feather and related products } \\
\text { and caps }\end{array}$ & $\begin{array}{l}\text { Apparel accessories \& other apparel } \\
\text { Clothing \& clothing accessories } \\
\text { Footwear } \\
\text { Leather \& hide tanning and finishing } \\
\text { Other leather \& allied products }\end{array}$ \\
\hline $\begin{array}{l}\text { Processing of timber, manufacture of wood and } \\
\text { manufacture of furniture bamboo, rattan, palm } \\
\text { and straw products }\end{array}$ & $\begin{array}{l}\text { Furniture, homeware \& related products (consumer products) } \\
\text { Furniture, homeware \& related products (textiles) } \\
\text { Furniture, homeware \& related products (wood products) } \\
\text { Other (wood products) } \\
\text { Wood products }\end{array}$ \\
\hline $\begin{array}{l}\text { Manufacture of paper and paper products, } \\
\text { manufacture of articles for culture, education and } \\
\text { sport activities }\end{array}$ & $\begin{array}{l}\text { Converted paper products } \\
\text { Dolls, toy, \& games } \\
\text { Printing \& related activities } \\
\text { Pulp, paper, \& paperboard }\end{array}$ \\
\hline Processing of petroleum and coking & $\begin{array}{l}\text { Natural, liquefied and compressed gas } \\
\text { Other petroleum \& coal products } \\
\text { Petroleum bulk stations \& terminals } \\
\text { Petroleum refineries }\end{array}$ \\
\hline Manufacture of chemical materials & $\begin{array}{l}\text { Basic chemicals } \\
\text { Biological products (except diagnostic) } \\
\text { Cosmetics, perfume, personal care \& household products } \\
\text { General medical \& surgical hospitals } \\
\text { In-vitro diagnostic substances } \\
\text { Medical equipment \& supplies } \\
\text { Medicinal \& botanical } \\
\text { Other (biotechnology) } \\
\text { Other chemical products \& preparation } \\
\text { Pesticide, fertilisers \& other agricultural chemicals } \\
\text { Pharmaceutical preparations } \\
\text { Soap, cleaning compounds, \& toilet preparation } \\
\text { Urethane, foam products \& other compounds }\end{array}$ \\
\hline Manufacture of non-metallic mineral products & $\begin{array}{l}\text { Cement \& concrete products } \\
\text { Clay product \& refractory } \\
\text { Glass \& glass products } \\
\text { Laminated plastics plates, sheets \& shapes } \\
\text { Other non-metallic mineral products } \\
\text { Other plastics products } \\
\text { Other rubber products } \\
\text { Plastic bottles } \\
\text { Plastic pipes, pipe fitting \& unlaminated profile shapes } \\
\text { Plastics \& rubber industry machinery } \\
\text { Plastics packaging materials \& unlaminated film \& sheets } \\
\text { Rubber hoses \& belting }\end{array}$ \\
\hline Smelting and pressing of metals & $\begin{array}{l}\text { Alumina \& aluminum production and processing } \\
\text { Architectural \& structured metals } \\
\text { Forging \& stamping }\end{array}$ \\
\hline
\end{tabular}




\begin{tabular}{|c|c|}
\hline & $\begin{array}{l}\text { Foundries } \\
\text { Iron \& steel mills \& ferroalloy } \\
\text { Nonferrous metal production \& processing }\end{array}$ \\
\hline Manufacture of metal products & $\begin{array}{l}\text { Coating, engraving, heat treating, \& allied activities } \\
\text { Machine shops, turned products, screws, nuts \& bolts } \\
\text { Other (metals) } \\
\text { Other fabricated metal products } \\
\text { Steel products }\end{array}$ \\
\hline $\begin{array}{l}\text { Manufacture of general and special purpose } \\
\text { machinery }\end{array}$ & $\begin{array}{l}\text { Agriculture, construction, \& mining machinery } \\
\text { All other industrial machinery } \\
\text { Commercial \& service industry machinery } \\
\text { Electro medical and electrotherapeutic apparatus } \\
\text { Engines \& turbines } \\
\text { Food product machinery } \\
\text { General purpose machinery } \\
\text { Metalworking machinery } \\
\text { Other (business machines \& equipment) } \\
\text { Other (medical Devices) } \\
\text { Paper industry machinery } \\
\text { Power transmission equipment } \\
\text { Sawmill \& woodworking machinery } \\
\text { Textile machinery }\end{array}$ \\
\hline Manufacture of transport equipment & $\begin{array}{l}\text { Aircraft } \\
\text { Aircraft engines, other parts \& auxiliary equipment } \\
\text { All other transportation (automotive OEM) } \\
\text { Automobiles } \\
\text { Boiler, tank, \& shipping container } \\
\text { Heavy duty trucks } \\
\text { Light trucks \& utility vehicles } \\
\text { Motor vehicle body \& trailers } \\
\text { Motor vehicle brake systems } \\
\text { Motor vehicle electrical \& electronic equipment } \\
\text { Motor vehicle gasoline engines \& engine parts } \\
\text { Motor vehicle seating \& interior trim } \\
\text { Motor vehicle stamping } \\
\text { Motor vehicle steering \& suspension components } \\
\text { Motor vehicle transmission \& power train parts } \\
\text { Motorcycle, bicycle, \& parts } \\
\text { Other (space \& defense) } \\
\text { Other motor vehicle parts } \\
\text { Railroad rolling stock } \\
\text { Ships \& boats } \\
\text { Support activities for transportation } \\
\text { Tires }\end{array}$ \\
\hline $\begin{array}{l}\text { Manufacture of electrical machinery and } \\
\text { equipment }\end{array}$ & $\begin{array}{l}\text { All other electrical equipment \& components } \\
\text { Batteries } \\
\text { Electric lighting equipment } \\
\text { Electrical equipment } \\
\text { Household appliances } \\
\text { Spring \& wire products } \\
\text { equipment manufacturing } \\
\text { Wiring devices }\end{array}$ \\
\hline $\begin{array}{l}\text { Manufacture of communication equipment, } \\
\text { computers and other electronic equipment }\end{array}$ & $\begin{array}{l}\text { Audio \& video equipment } \\
\text { Communication \& energy wires \& cables } \\
\text { Communications equipment } \\
\text { Computer \& peripheral equipment } \\
\text { Other (Consumer Electronics) } \\
\text { Other telecommunications } \\
\text { Satellite telecommunications } \\
\text { Semiconductor machinery }\end{array}$ \\
\hline
\end{tabular}


Manufacture of measuring instruments and machinery for cultural activity and office work

Other manufacturing

Production and distribution of electricity, gas and water
Semiconductors \& other electronic components

Wired telecommunication carriers

Wireless telecommunication carriers

Measuring \& control instruments

Navigational instruments

Office supplies

Asphalt paving, roofing, \& saturated materials

Hardware

Jewelry \& silverware

Other (building \& construction materials )

Other (consumer products )

Other (paper, printing \& packaging)

Paints, coatings, additives $\&$ adhesives

Printing machinery \& equipment

Biomass power

Fossil fuel electric power

Geothermal electric power

Hydroelectric power

Nuclear electric power generation

Other electric power generation (alternative/renewable energy)

Other electric power generation (coal, oil and natural gas)

Solar electric power

Wind electric power

Construction

Architectural, engineering, \& related services

Commercial \& institutional building construction

Heavy \& civil engineering

Industrial building construction

Residential building construction

Wholesale and retail trade

Building material \& garden equipment \& supplies dealers

Electronics \& appliances stores

Gasoline stations

General merchandise stores

Miscellaneous store retailers

Motor vehicle \& parts dealers (automotive components)

Motor vehicle \& parts dealers (automotive OEM)

Non-store retailers

Specialty trade contractors

Wholesale Trade (consumer goods)

Wholesale Trade (food \& tobacco)

Traffic, transport, storage and post

Air transportation

All other transportation (non-automotive OEM)

Freight/distribution services

Other (aerospace)

Pipeline transportation of crude oil

Pipeline transportation of natural gas

Postal service

Rail transportation

Transit \& ground passenger transportation

Warehousing \& storage

Water transportation

Hotels and catering services

Accommodation

Food \& beverage stores (food \& tobacco)

Food services

Information transmission, computer services and software

All other information services

Cable \& other subscription programming

Computer facilities management services

Computer systems design services

Custom computer programming services

Data processing, hosting, \& related services 


\begin{tabular}{|c|c|}
\hline & $\begin{array}{l}\text { Internet publishing \& broadcasting \& web search } \\
\text { Other (software \& IT services) } \\
\text { Software publishers, except video games } \\
\text { Video games, applications and digital content }\end{array}$ \\
\hline Financial intermediation & $\begin{array}{l}\text { Corporate \& investment banking } \\
\text { Insurance } \\
\text { Investment management } \\
\text { Other (financial services) } \\
\text { Retail banking }\end{array}$ \\
\hline Real estate & $\begin{array}{l}\text { Other (real estate) } \\
\text { Real estate services }\end{array}$ \\
\hline Leasing and business services & $\begin{array}{l}\text { Accounting, tax preparation, bookkeeping, \& payroll services } \\
\text { Advertising, PR, \& related } \\
\text { Environmental consulting services } \\
\text { Legal services } \\
\text { Management consulting services } \\
\text { Other support services } \\
\text { Rental \& leasing services }\end{array}$ \\
\hline $\begin{array}{l}\text { Scientific research, technical service and } \\
\text { geologic prospecting }\end{array}$ & $\begin{array}{l}\text { Professional, scientific \& technical services } \\
\text { Specialised design services }\end{array}$ \\
\hline Management of water conservancy, environment & $\begin{array}{l}\text { Water, sewage \& other systems } \\
\text { Waste management \& remediation services }\end{array}$ \\
\hline Services to households and other services & $\begin{array}{l}\text { Ventilation, heating, air conditioning, and commercial } \\
\text { refrigeration }\end{array}$ \\
\hline Education & $\begin{array}{l}\text { Business schools, computer \& management training } \\
\text { Educational support services } \\
\text { Schools, colleges, universities, \& professional schools }\end{array}$ \\
\hline Health, social security and social welfare & $\begin{array}{l}\text { Health \& personal care stores } \\
\text { Offices of physicians, dentists, \& other healthcare practitioners } \\
\text { Outpatient care centres \& medical \& diagnostic laboratories }\end{array}$ \\
\hline Culture, sports and entertainment & $\begin{array}{l}\text { Amusement \& theme parks } \\
\text { Motion picture \& sound recording industries } \\
\text { Museums, historical sites, \& similar } \\
\text { Newspaper, periodical, book, \& directory publishers } \\
\text { Other amusement \& recreation industries } \\
\text { Performing arts, spectator sports, \& related } \\
\text { Radio \& TV broadcasting } \\
\text { Sporting goods, hobby, books \& music } \\
\text { Travel arrangement \& reservation services }\end{array}$ \\
\hline
\end{tabular}

Note: The FDI Markets database for greenfield investment projects uses a sector classification system that needed to be manually matched to the Chinese national classification GB/T 4754-2011.

Source: Authors' compilation. 


\section{Annex C. Definition and source of variables}

49. This annex provides a summary of the sources and construction of the variables for the analysis that were not readily available at the industry level including employment, value added, output, wage and the relevant deflators. The analysis in this paper uses data from 34 sectors, 16 manufacturing, agriculture, construction, utilities and 15 services.

\section{Employment}

50. Employment data by sector are not available for China. The number of employed persons at yearend in urban and rural areas is used for total employment. Urban employment is obtained partly from the number of employed persons in urban units, partly from the number of employed persons in urban private enterprises and self-employed individuals, both series are available by sector. The sum of these series, however, is less than total urban employment and there is no publicly available information about the sectoral distribution of the remainder. This paper used the sectoral distribution of urban employment as in the Population Census of 2000 and 2010 to interpolate the remainder across sectors.

51. For rural employment, only the number of engaged persons in rural private enterprises and selfemployed individuals is available by sector. The difference between total rural employment and this series is again interpolated across sectors using the sectoral distribution of rural employment as in the Population Census of 2000 and 2010. Then for each sector, urban and rural employment obtained the above way are added up to get total employment in that sector. This way employment in 19 sectors can be compiled, but there is only one single series for manufacturing without any detail on sub-industry employment.

52. For manufacturing sub-sectors employment data are available only for above-threshold firms, not for all firms. Therefore, for the above-threshold part of employment, the actual sector shares are used, while for the remaining part, the shares from the Population Census. First, the share of above-threshold employment to employment in the Economic Census is calculated for each census year, which are 2004, 2008 and 2013 (2018 data were not available at the time of writing this paper). For 2003 and 2004 the 2004 share, for 2008 the 2008 share and for 2013 the 2013 share is used. For the years in between, the shares are interpolated. For the remaining part (which are the below-threshold firms and calculated as the difference between the manufacturing employment and above threshold firms' employment), the Population Census' sectoral distribution is applied (as above) and the two parts are added up by manufacturing sub-sector.

\section{Value added}

53. The National Bureau of Statistics publishes value-added data for 19 industries, agriculture, construction, utilities, 15 services and a single series for manufacturing, no value added data for manufacturing sub-sectors. For those, the Input-Output Tables are used, which are available for 2002, 2005, 2007, 2010, 2012, 2015 and 2017. For the years where no IO tables were published, the sub-sector shares are assumed the same as in the last available year for which there is an IO table and the total value added for manufacturing is interpolated using those shares. 


\section{Output}

54. The National Bureau of Statistics publishes output data for 19 industries for 2002, 2005, 2007, 2010, 2012, 2015 and 2017. Output data for manufacturing sub-sectors are estimated by using the value added data estimated above and the share of value added and output for the years where IO tables were published. For the interim years, the same share is assumed as in the last year for which 10 data were published.

\section{Fixed asset investment}

55. For fixed asset investment, the official sector-level fixed asset investment not including rural households series is used, published by the National Bureau of Statistics. This series is subject to a number of caveats with the major one being the inclusion of the purchase of second-hand assets such as land in the data. As no decomposition is publicly available that would allow delineating this impact, the series used in the analysis continues to be subject to this flaw.

\section{Wage}

56. The National Bureau of Statistics does not publish wage data by sector for the overall economy and for rural wages no substitutes are available, therefore the average wage data for employees in urban firms from the China Labour Statistical Yearbook is used. For industry concordance, weighted averaging is applied. The weight is employment.

\section{Deflators}

57. The National Bureau of Statistics does not publish sector-level value added or output deflators, but for the 19 industries (agriculture, construction, utilities, 15 services and a single manufacturing series) they can be calculated using data for 9 industries for which both nominal and real data series are published. Those industries are agriculture, industry, construction, wholesale and retail, traffic, transport, storage and post, hotels catering and services, financial services, real estate and other services. For the industry subsectors, the respective producer price indices are used and for the services where no specific deflator is available, the "other services" deflator. For value added and output the same deflators are used. For fixed asset investment, the fixed asset investment deflator is used, which is not available by sector, only a single deflator for the whole economy. 